\title{
Sjećanja Franje Mikulića na Hrvatsko proljeće
}

U radu se problematizira do sada $u$ historiografskim istraživanjima nekonzultirani izvor za povijest hrvatskog reformnog pokreta, objavljena sjećanja sudionika toga procesa - Franje Mikulića. Mikulić je bio član Saveza komunista, predsjednik Skupštine općine Jastrebarsko i lokalnog ogranka Matice hrvatske. Poznavao je i surađivao $\mathrm{s}$ nizom istaknutih imena hrvatskog reformnog pokreta, popularno zvanog Hrvatsko proljeće, a u svojim je osvrtima na te događaje ponudio značajan broj nepoznatih detalja o pojedinim osobama, bilo pristašama bilo protivnicima reformnog pokreta. Pokazao je kako se neke od njih ne može isključivo promatrati u spomenutim kategorijama, već da je potrebno finije nijansiranje. Ovaj izvor značajan je i po tome što se pojavio početkom osamdesetih godina, dakle nepunih deset godina prije urušavanja jugoslavenskog komunističkog režima i pojave mogućnosti da se objavljuju memoari sudionika ugušenog reformnog pokreta. Također, valja ga uzimati u obzir u analizama raznih varijanti ideje o hrvatskome miru ili pomirbi.

\section{Uvod}

Hrvatski reformni pokret, popularno zvan Hrvatsko proljeće ${ }^{1}$, jedan je od najvažnijih skupova procesa i događaja u povijesti Hrvatske između završetka Drugog svjetskog rata te propasti komunističkog sistema i nastanka samostalne i demokratske Republike Hrvatske. S obzirom na njegovu kompleksnost i heterogenost, može se ponuditi niz definicija koje ga u većoj ili manjoj mjeri mogu opisati. Prema jednoj od njih, radilo se o pokretu koji je inicirao politički vrh - savezni, jugoslavenski te hrvatski, republički. Jedan je dio potonjeg faktora posebno prednjačio u zahtjevima za reformom postojećeg sustava, prvenstveno u upravnoj i ekonomskoj sferi. Taj proces otvorio je prostor i nekim drugim sna-

Ovaj naziv koristi se po uzoru na kratkotrajni reformni pokret u Čehoslovačkoj, zvan Praško proljeće, a koji se javio i koji je isto tako ugušen 1968. godine. Do sada još nije precizno utvrđeno tko je i kada prvi tako okvalificirao hrvatski reformni pokret. Prema autorovim istraživanjima, jedno od najranijih korištenja tim terminom javlja se u listu hrvatske političke emigracije Hrvatska Država, koji je izlazio u Saveznoj Republici Njemačkoj sredinom 1970. godine. Vidi: Quo vadis?. Hrvatska Država, svibanj - lipanj 1970., 3. Taj je termin uskoro postao općeprihvaćen među hrvatskim političkim emigrantima. Osim hrvatskog reformnog pokreta, pojavljuje se i termin liberalno-nacionalni pokret. BATOVIĆ 2010. 
gama u društvu, kojima se do tada onemogućavalo iznošenje mišljenja o nekim od ključnih političkih i društvenih tema. ${ }^{2}$

Slom hrvatskog reformnog pokreta obilježile su snažne turbulencije u hrvatskoj Partiji, zatim znatnom dijelu intelektualne elite, ali i u dijelovima društva. Najistaknutiji vodeći reformno orijentirani komunisti, uključujući prva dva, najzvučnija imena - Savku Dabčević-Kučar i Miku Tripala - bili su prisiljeni dati ostavke na svoje dotadašnje položaje. Ostavke i smjenjivanja zahvatili su i niže grane partijskog sustava, dok je dio vrha Matice hrvatske, kao i studentskog pokreta, bio izveden pred sud i kažnjen zatvorskim kaznama. Naredni je period u javnosti nazvan „hrvatska šutnja“. Stoga je na analize i sjećanja sudionika pokreta, pored

Ugrubo gledajući, došlo je do formiranja triju centara hrvatskog reformnog pokreta - reformski orijentiranog dijela Saveza komunista Hrvatske, zatim u odnosu na prethodni period pojačanog i modificiranog djelovanja najstarije hrvatske kulturne ustanove - Matice hrvatske i studentskog pokreta, koji izlazi na scenu u završnoj fazi pokreta. Ove sastavnice reformnog pokreta nisu međusobno surađivale, iako su određeni pokušaji u tome pravcu postojali, a niz vodećih članova Matice bili su npr. i članovi Partije. Ograničeno javno djelovanje snaga izvan SKH, elemenata koji nisu u potpunosti slijedili trenutnu partijsku liniju, bilo je moguće zato što je reformno orijentirani dio vrha hrvatske Partije odlučio dopustiti takvu mogućnost želeći, kako je zapisala Savka Dabčević-Kučar, neistomišljenike poraziti na političkome polju. U takvom novom omjeru snaga, reformni dio vrha Partije ni u kojem slučaju nije namjeravao ugroziti vlastiti monopol na vlast. Međutim, dopustio je određenu politizaciju društva, želeći dobiti otvorenu podršku za politiku reformiranja Socijalističke Republike Hrvatske i Jugoslavije. Cilj je bila redefinicija položaja hrvatske federalne jedinice u Jugoslaviji, kao i promjena društvenog i političkog sustava. To je uključivalo i raskidanje s dotadašnjom praksom označavanja niza iskaza hrvatskih nacionalnih osjećaja nacionalizmom i ustaštvom. U tome kontekstu DabčevićKučar ističe kako je za nju 1971. godina predstavljala metamorfozu nasilno gušenih hrvatskih nacionalnih osjećaja ,,u golemu nacionalnu energiju nužnu za brze pomake prema ostvarivanju vlastitih prava“", zatim buđenje svijesti o vlastitom identitetu, želju za stvaranjem modernijeg i demokratskijeg društva te onu za nastankom suverene države, ,iako još u okvirima federacije“. Nadalje, njeni te napori njenih istomišljenika podrazumijevali su poštovanje ljudskih prava, popravljanje „slabosti socijalističkih društava“, kao i „pokušaj reduciranja, iako ne potpuno detroniziranje, uloge komunističke partije kao konačna arbitra svekolikih zbivanja“. (DABČEVIĆ-KUČAR 1997: 17, 654-657). Dugoročni cilj Matice hrvatske i studentskog pokreta, barem najvećeg dijela njihovih članova, odnosno sudionika, bila je samostalna hrvatska država. No, zbog nemogućnosti javnog iznošenja takvog programa, oba su elementa u nizu slučajeva izražavala potporu reformnom dijelu hrvatskog vodstva jer su zahvaljujući njegovoj novoj politici i dobili prostor za stanovito slobodnije izražavanje. Osim toga, proces snaženja hrvatskog položaja unutar Jugoslavije, na čemu je radio reformno orijentirani dio hrvatskih komunista, shvaćali su kao prvi korak prema hrvatskoj samostalnosti. To, pak, nije značilo da nije dolazilo do sukoba i neslaganja između reformno orijentiranog vodstva SKH te Matice i studentskog pokreta. Međutim, i matičari i studenti razilazili su se u, generalno govoreći, taktičkim pitanjima jer su studenti bili skloniji nešto radikalnijim istupima, što se ogledalo i u poznatom studentskom štrajku koncem 1971. godine. Potonji su onda iskoristili protivnici reformnog pokreta unutar Hrvatske te oni na saveznoj razini, kao izgovor za njegovo okončanje. O ovoj problematici općenito vidi: BATOVIĆ 2010; JAKOVINA 2012; PONOŠ 2007. Također vidi: GOLDSTEIN 2008: 491-551; MUJADŽEVIĆ 2011: 215-303; RADELIĆ 2008: 330-483; SADKOVICH 2010: 187-202. 
onih službenih, partijskih, kao i za čitav niz problema i otvorenih pitanja, valjalo čekati urušavanje komunističkog sistema. ${ }^{3}$

Pomnija i sustavnija istraživanja pokazala su da ipak nije bilo nužno čekati devedesete da bi se sjećanja nekih sudionika reformnog pokreta publicirala. Naime, omanji broj do tada politički i/ili društveno aktivnih osoba napustio je Jugoslaviju, prije ili nakon izdržavanja zatvorske kazne koja im je bila dosuđena zbog njihovih uloga u pokretu. Neki od njih nastavili su se u emigraciji baviti političkim radom, ostavivši zamjetan trag. Među njima bio je i Franjo Mikulić, koji se ne samo od ostalih najnovijih političkih izbjeglica nego i od gotovo svih ostalih hrvatskih političkih emigranata razlikovao po tome što je bio član Saveza komunista. ${ }^{4} \mathrm{Za}$ ovaj rad još je bitnije istaknuti kako je upravo on ostavio najsustavnije sjećanje na znatan broj nekih od najvažnijih protagonista hrvatskog reformnog pokreta, od kojih je većinu osobno poznavao i s njima u određenom obujmu surađivao, uz vlastite ocjene i pogled na ta zbivanja. Njegova sjećanja i analize, koliko je poznato, do sada se ni u kojoj mjeri nisu uzimali u obzir u historiografskim ili bilo kojim drugim analizama koje su se bavile hrvatskim reformnim pokretom. S obzirom na njegovu poziciju te spomenuta poznanstva, njegovi radovi predstavljaju važan izvor, pogotovo zato što su nastali i bili objavljeni dok se o tome u Hrvatskoj javno nije smjelo govoriti.

Cilj ovoga rada jest rekonstruirati Mikulićevo političko djelovanje s kraja šezdesetih i početka sedamdesetih godina, prvenstveno na temelju dokumenata iz njegova dosjea koji su sačinili represivni organi kako bi se provjerili temelji na kojima je Mikulić bazirao pojedine dijelove svojih memoara. Konkretnije, iznijet će se njegovi pojedini politički potezi i nastojanja, odnosno poznanstva i suradnja s nekim od istaknutih osoba, koje se u većoj ili manjoj mjeri doživljavalo kao „nositelje“ reformnog pokreta (od pristalica i protivnika). Propitat će se neke od temeljnih odrednica Mikulićevih tekstova, zbog kojih se ovome povijesnome

Da se radilo o temi o kojoj se jedva čekalo nešto kazati, svjedoči i činjenica kako su već 1990. godine izašle dvije knjige o njoj. Prvu je napisao Tripalo, jednostavnog naziva Hrvatsko prolje$c$ é, a drugu jedan od predvodnika struje u hrvatskoj Partiji koja se suprotstavljala reformnome pokretu, Jure Bilić, koji je svoje djelo naslovio: '71, koja je to godina?. Za njima će uslijediti brojni duži ili kraći memoari u obliku monografija, članaka, zbornika i slično, a prema opsegu i kvaliteti među njima još uvijek prednjači dvotomno djelo Savke Dabčević-Kučar '71: hrvatski snovi i stvarnost, koje je izdano 1997. godine. Uzgred valja spomenuti kako je hrvatska historiografija dala niz djela koja tematiziraju pojedine aspekte hrvatskog reformnog pokreta ili je tome fenomenu posvećen znatan prostor u pregledima hrvatske povijesti 20. stoljeća, odnosno njegove druge polovine. Ipak, još uvijek postoji potreba za cjelovitim historiografskim radom koji bi se u potpunosti fokusirao na ovu problematiku, pokušavajući obuhvatiti što više njenih raznih aspekata. TRIPALO 1990; BILIĆ 1990; DABČEVIĆ-KUČAR 1997.

4 U inozemstvo je izbjegao i Mato Novačić, nekadašnji predsjednik Skupštine općine Slavonska Požega, no nije se nastavio baviti političkim radom, niti je ostavio pisane tragove o svojim mislima i sjećanjima vezanim za reformni pokret. KRAŠIĆ́ 2016: 236-237. 
izvoru pridaje važnost. Pozornost će se u stanovitoj mjeri posvetiti i Mikulićevoj karijeri u emigraciji i životnome putu jer su u tome periodu nastali memoari. Budući da se radi o korištenju memoarskim zapisima kao povijesnim izvorom, od velike je važnosti proniknuti u položaj i stanje autora takvih zapisa, odnosno u njegove motive zbog kojih ih je pisao. Iz Mikulićevih tekstova ekstrahirat će se njegove temeljne poruke, zaključci o hrvatskom reformnom pokretu, koji nisu zanimljivi tek kao još jedna ocjena toga fenomena od strane sudionika pokreta, nego ujedno predstavljaju novost $\mathrm{u}$ rezoniranju hrvatskih političkih emigranata o hrvatskoj državotvornoj ideji te ideji hrvatske pomirbe.

\section{O Hrvatskom proljeću u emigraciji}

Važnost hrvatskog reformnog pokreta očitovala se i u tome što mu je hrvatska politička emigracija pridavala veliku pozornost. Niz je emigranata budno pratio procese i događaje u Jugoslaviji i Hrvatskoj, stoga su o tim temama nastali brojni članci u emigrantskim tiskovinama od sredine šezdesetih do sredine sedamdesetih. ${ }^{5}$ O Proljeću se ponovno počelo intenzivnije pisati nakon što su pojedini sudionici pokreta, koji su izbjegli iz Jugoslavije, stali iznositi svoja sjećanja i interpretacije toga vremena. Temeljni motiv za oživljavanje te teme na stranicama emigrantskih novina i časopisa bila je činjenica da su se te nove političke izbjeglice koristile interpretacijama Proljeća u predstavljanju svojih političkih agenda. Štoviše, neki su legitimirali svoje političko istupanje u emigraciji na temelju činjenice da su bili, u određenim obujmima, dio strujanja u Hrvatskoj s kraja šezdesetih i početka sedamdesetih.

Pored Mikulića, koji je u nekim situacijama nastupao upravo na spomenuti način, o Proljeću su, a u kontekstu tadašnjih rasprava hrvatske političke emigracije, pisali Bruno Bušić ${ }^{6}$ i Zlatko Markus ${ }^{7}$. Bušićev rad u emigraciji bio je raznolik, a

\footnotetext{
O tome djelomično vidi: KRAŠIĆ 2016.
}

6 Bruno Bušić još je kao srednjoškolac došao u sukob s režimom. Kasnije je bio djelatnik Instituta za historiju radničkog pokreta, kojemu je na čelu bio Franjo Tuđman, pisao je za popularni Hrvatski književni list, a 1971. godine za još popularniji list Matice hrvatske-Hrvatski tjednik. Nakon izdržavanja zatvorske kazne brutalno je pretučen u središtu Dubrovnika, pa je koncem 1974. godine ilegalno napustio Jugoslaviju. Postao je točka okupljanja jednog dijela političkih emigranata, uglavnom mlađe životne dobi, koji su držali kako su sva sredstva, uključujući nasilje, dopuštena u borbi za stvaranje samostalne hrvatske države. Sredinom sedamdesetih velik dio hrvatske političke emigracije ujedinio se u krovnu organizaciju Hrvatsko narodno vijeće. Na drugim izborima za to tijelo, održanim 1977. godine, Bušić je, iako s iznimno kratkim emigrantskim stažem u odnosu na niz ostalih političkih emigranata, dobio najveći broj glasova. Iduće godine sredinom listopada smaknut je u Parizu, najvjerojatnije od strane jugoslavenskih obavještajnih službi. Za osnovne biografske podatke o Bušiću vidi: MIJATOVIĆ 2009.

7 Slično kao i Bušić, pisao je za HKL i HT. Markus je napustio Jugoslaviju odmah nakon sloma reformnog pokreta i početkom 1972. godine počeo se javljati sa stranica emigrantskog časopisa 
dio toga otpadao je i na pisanje članaka u emigrantskim tiskovinama. U nekima od njih osvrtao se na svoja iskustva u zemlji, primjerice, s represivnim aparatom, ali i na doživljaje i zapažanja iz vremena reformnog pokreta. Indirektno je odao stanovito priznanje reformnom dijelu hrvatskog rukovodstva kako je učinilo određene pomake u smjeru poboljšanja položaja hrvatskog naroda u Jugoslaviji, ali je jasno naglašavao kako je ono bilo u raskoraku s najvećim dijelom hrvatskog naroda, koji je želio samostalnu državu, a ne reformiranu Jugoslaviju. „Narod je bio u zanosu“", pisao je Bušić, no materijalno iscrpljen, i više se nije mogao zadovoljiti pjevanjem hrvatskih pjesama i mahanjem zastavama. $S$ druge strane, neki su baš zbog takvih stvari vjerovali da imaju svoju državu pa je Bušić „odahnuo“ kada je došlo do sloma pokreta jer su sve ,zablude“ rasplinute. Držao je i kako nije dovoljno učinjeno da pristalice spomenutog dijela rukovodstva uđu u sve važnije strukture vlasti u Hrvatskoj. Slično tome, bio je razočaran što je, prema njemu, propuštena ogromna prilika da se taj snažan nacionalni osjećaj i revolucionarno raspoloženje nisu kanalizirali u snažniji otpor režimu. ${ }^{8}$

Markus je, pak, bio daleko najplodniji i najtalentiraniji pisac među njima, iako je odmicanjem vremena njegova polemičnost u nekim slučajevima prerasla u neargumentirane napade i objede na račun političkih neistomišljenika u emigraciji. Mnogo je više pisao o Proljeću od Bušića, nudeći znatnim dijelom idealiziranu sliku reformnog pokreta, pogotovo osoba iz vrha hrvatske Partije, poput Dabčević-Kučar i Tripala, Pere Pirkera i drugih. Za razliku od, na primjer, Bušića, ali i mnogih drugih emigranata, koji su kao perjanice reformnog pokreta vidjeli Maticu i posebno studentski pokret, Markus je upravo u dijelu hrvatskih komunista pronalazio spiritus movens Hrvatskog proljeća. I ne samo to, bio je uvjeren kako bi Savka Dabčević-Kučar i/ili Miko Tripalo trebali stati na čelo budućih hrvatskih državotvornih strujanja, držeći kako za to imaju legitimitet. ${ }^{9}$ Treba kazati i to kako je Markus iznio niz simpatija, doduše, često neodređenih, na račun socijalizma kao društvenog sustava. Isto tako, obilato se koristio isku-

koji je izlazio u Londonu - Nove Hrvatske - a koji je pod vodstvom Jakše Kušana bio glasilo uglavnom mlađe generacije političkih izbjeglica. Grupa se zalagala za korištenje diplomatskim, propagandnim i drugim nenasilnim metodama u borbi protiv jugoslavenskog komunističkog režima, nastojeći podržavati demokratizacijske i liberalizacijske procese u zemlji, što je posebno došlo do izražaja u vrijeme egzistiranja hrvatskog reformnog pokreta ili, pak, koncem osamdesetih, držeći da bi u njima trebao sudjelovati i barem jedan dio hrvatskih komunista. Više o Markusu, ali i Bušiću, vidi u: KUŠAN 2000. O reagiranjima Nove Hrvatske na procese u Hrvatskoj i Jugoslaviji koncem šezdesetih i početkom sedamdesetih vidi: KRAŠIĆ 2016: 52-56. O pisanju Nove Hrvatske u osamdesetima vidi opširno u: MATIŠIĆ 2017.

8 Bruno Bušić govori za HT Danicu, Hrvatski tjednik Danica, 6. lipnja 1977., 8. Bušić sličnu poruku odašilje i u ovim člancima: Bruno Bušić govori za HT Danicu, Hrvatski tjednik Danica, 13. lipnja 1977., 8-9; Hrvatska danas - i Rusija, isto, 11. srpnja 1977., 1, 8-9, Bruno Bušić odgovara na pitanja Hrvatske borbe, Hrvatska borba, prosinac 1975., 6-7.

$9 \quad$ Vrijeme za Miku Tripala, Hrvatski list, 1. svibnja 1982., 3, 10. 
stvom i postojanjem reformnog pokreta u razgovorima i polemikama s političkim protivnicima u emigraciji. Stoga taj njegov motiv valja uzimati u obzir kada se analiziraju njegovi dojmovi, zapažanja $i$ analize toga fenomena. ${ }^{10}$

Mikulić je u emigraciji - pogotovo od 1977. godine, kada je izabran za predsjednika Sabora Hrvatskog narodnog vijeća, organizacije koja je okupila znatan broj hrvatskih političkih emigranata - barem u javnim nastupima, odašiljao prilično pomirljive poruke o potrebi jedinstva i zajedništva Hrvata svih političkih opcija. Tako je s Danijelom Crljenom, predsjednikom Časnog suda HNV-a, nekadašnjim ustaškim pukovnikom i članom delegacije koja je pregovarala s Britancima o predaji vojske NDH, povodom izbora za Treći sabor HNV-a ovako istupio: „Integracija nosilaca 10. Travnja i preporodnog Hrvatskog proljeća, očeva i sinova ujedinjenih istim državotvornim idealom, simbolizira danas nužni kontinuitet stoljetne hrvatske borbe za slobodu“ “. ${ }^{11}$ Međutim, u nekim raspravama i polemikama i on se koristio iskustvom hrvatskog reformnog pokreta pa je tako, primjerice, naslovio jedan članak „Tko to Hrvatskom proljeću priprema novo Karađorđevo“"12, u kojemu sebi i svojoj političkoj struji nastoji dati legitimitet za političko djelovanje i pozivanjem na sudjelovanje $\mathrm{u}$ hrvatskom reformnom pokretu. ${ }^{13} \mathrm{~S}$ druge, pak, strane, Mikulićevi osvrti na hrvatski reformni pokret, koji su u fokusu ovoga rada, daleko su sustavniji od njegovih ranijih članaka, opširniji te znatnim dijelom lišeni namjere korištenja u svrhe političkih nastojanja u emigraciji.

\section{Mikulićevo djelovanje u Hrvatskoj koncem šezdesetih i početkom sedamdesetih}

Već je rečeno kako će Mikulićev osobni dosje biti svojevrstan lakmus-papir, koji će služiti kao sredstvo testiranja, tj. provjeravanja osnova za njegova sjećanja na razdoblje reformnog pokreta. Međutim, osobnim dosjeima, sačinjenim od strane jugoslavenskih obavještajnih službi i represivnih organa, treba uvijek pristupati sa znatnom dozom opreza i kritičnosti. Naime, niz je razloga zbog kojih ta vrsta povijesnog izvora u brojnim slučajevima vrvi tendencioznim i netočnim podacima.

10 O Markusovim člancima u Novoj Hrvatskoj do sredine sedamdesetih vidi u: KRAŠIĆ 2016.: 62-69. U razdoblju druge polovine sedamdesetih i početka osamdesetih vidi brojne članke u kojima se Markus referira na Hrvatsko proljeće u sljedećim listovima hrvatske političke emigracije: Hrvatski tjednik Danica, Hrvatska borba, Otpor, Hrvatski list i Hrvatski tjednik. Predizborna poruka članovima Hrvatskog narodnog vijeća, Hrvatski list, kolovoz 1979., 11.

12 Radi se o referiranju na sjednicu Predsjedništva Centralnog komiteta Saveza komunista Jugoslavije, započetu 1. prosinca 1971. godine u Karađorđevu, na kojoj je reformnoj struji u hrvatskom vodstvu Tito uskratio daljnju potporu i toleranciju za njenu politiku, što je u narednom periodu rezultiralo ostavkama osoba spomenute političke orijentacije te okončanjem pokreta. Korištenje terminom Karađorđevo u kontekstu hrvatskog reformnog pokreta poprimilo je i simboličko značenje.

13 Tko to Hrvatskom proljeću priprema novo Karađorđevo, Hrvatski tjednik Danica, 25. kolovoza 1978., 8. 
U znatnom broju slučajeva to je posljedica namjere režima da se kompromitira političkog neistomišljenika, često s lažnim optužbama. To se radilo s ciljem kreiranja osnovice za kazneni progon. Jedan od najčešćih postupaka bilo je prišivanje epiteta nacionalista, ustaše ili fašista takvim ljudima ili, pak, klerikalca. No, u stvarnosti se često radilo o tome da je netko tek pjevao pjesmu Ustani bane ili Vila Velebita, odnosno naprosto redovito pohađao mise u crkvi. Još je teža optužba bila ona za terorizam. S druge strane, treba kazati kako je bilo osoba u čijim su se istupima i djelovanjima mogli pronaći spomenuti elementi, npr. oni koji su zaista ispoljavali nacionalnu mržnju ili oni koji su planirali poduzimanje nasilnih činova protiv režima, što je nekima i pošlo za rukom. Ipak, na temelju višegodišnjih i vrlo opsežnih autorovih istraživanja ove problematike, broj prvih u daleko je višem postotku nadmašivao broj drugospomenutih. Nadalje, posljedica netočnih podataka u osobnim dosjeima moglo je biti tendenciozno izvještavanje suradnika obavještajnih službi. Valja se sjetiti i specifičnog ideološko-političkog odgoja operativnih radnika spomenutih službi, koji su tumačili neke od gore spomenutih pojava (iskazivanje nacionalnog i/ili vjerskog identiteta) u skladu s komunističkom ideologijom.

Mikulićev dosje ne predstavlja teško rješivu slagalicu, kako je to slučaj s osobnim dosjeima nekih drugih osoba. Takva ocjena bazira se na činjenici da je Mikulić pripadao poraženoj frakciji hrvatske Partije i njegov glavni krimen bilo je uglavnom provođenje politike koja je osuđena i odbačena koncem 1971. godine. Kada se odstrane ustaljene i klasične formule o nacionalizmu, šovinizmu i slično, a u kontekstu postavki politike koju je provodio reformni dio vrha hrvatske Partije, o čemu će detaljnije biti riječi, dobiva se prilično realna slika o Mikulićevu djelovanju. To se odnosi npr. na svjedočenja njegovih tadašnjih političkih neistomišljenika. Također, Mikulić je djelovao i kao član Matice hrvatske, dakle u okviru djelatnosti te institucije koja je bila dopuštena ili, bolje rečeno, u nizu elemenata tolerirana od vlasti do prosinca 1971. godine. Brojni podaci iz Mikulićeva dosjea odnose se na sastanke istaknutijih osoba iz Matice hrvatske, kojima je i on prisustvovao. Ocjene takvih događaja, s obzirom na dostupnu literaturu i druge izvore o djelatnosti dijela vrha Matice hrvatske, mogu se najvećim dijelom uzeti kao točne. Problematičniji su oni dijelovi koji govore o Mikulićevim istupima koji su ga dovodili na rub službene politike, pa i preko njega, što se odnosilo na istupe izvan jugoslavenskih i komunističkih okvira, o čemu će također biti više riječi. Pored spomenutog, složenijim za iščitavanje valja okarakterizirati i one dijelove koji govore o njegovim nacionalističkim istupima prema osobama srpske nacionalnosti. Zaključno, Mikulićev osobni dosje ostaje najbolji izvor za ostvarenje dijela izloženih namjera ovoga rada.

Mikulić je zbog svojeg političkog djelovanja od 1969. godine postao početkom 1972. predmet istrage $i$ bio pozvan na informativni razgovor. Ubrzo je uhićen $i$ protiv njega je podignuta optužnica, a potom je osuđen na dvije godine strogog 
zatvora. Odslužio je kaznu i sredinom 1974. godine izašao na slobodu, no vrlo brzo nakon toga protiv njega je podnesena kaznena prijava s optužbom da je izazivao nacionalnu mržnju prema Srbima. Ne želeći se suočiti s još jednom kaznom, Mikulić je pobjegao u inozemstvo. Za potrebe građenja slučaja protiv njega, Služba državne sigurnosti prikupila je velik broj podataka o njegovoj političkoj djelatnosti i ponašanju, uglavnom od spomenute 1969. godine.

Mikulić je rođen 1932. godine u selu Donja Kupčina. Jedan njegov poznanik izjavio je da se školovao kao dijete palog borca, s obzirom na to da mu je otac ubijen kao partizan 1943. godine, navodno od strane ustaša. Kasnije je završio učiteljsku školu. Ušao je u Partiju te postao predsjednik Općine Pisarovina, a nakon njezina ukidanja radio je u jednoj od najpoznatijih tvrtki u SR Hrvatskoj-Agrokombinatu. Prema svjedočenju stanovitog Mije Fureša, upravo je čelnik Agrokombinata, Ante Todorić, zajedno s već spomenutim Perom Pirkerom, zagrebačkim gradonačelnikom od 1963. do 1967. godine te sekretarom Izvršnog komiteta Centralnog komiteta Saveza komunista Hrvatske, nagovorio Mikulića da se kandidira na skupštinskim izborima Općine Jastrebarsko za odbornika. Pribavljeni su podaci kako se Pirker uoči izbora pohvalno izražavao o Mikuliću, zapravo lobirajući za njegov izbor.

Dokument naslova „Izvještaj o stanju u Savezu komunista Hrvatske u odnosu na prodor nacionalizma u njegove redove" CK SKH usvojio je početkom svibnja 1972. godine, a bio je rezultat rada komisije koja je zapravo propitivala uzroke i posljedice nastanka hrvatskog reformnog pokreta, odnosno Maspoka ili masovnog pokreta, kako su ga uglavnom zvali njegovi protivnici, nastojeći da termin poprimi pejorativno značenje. Pri stvaranju dokumenta koristili su se i brojni izvještaji s terena, a onaj za područje Općine Jastrebarsko sastavila je Milka Kufrin, tada članica Vijeća naroda Savezne skupštine SFRJ. U njemu je podcrtala kako je „prodor nacionalizma“ u Općinu počeo Mikulićevim dolaskom na njezino čelo. Kao i u nizu sredina u Hrvatskoj, dolazilo je do manjih ili većih sukoba među reformnom i unitarističkom strujom, iako se tim nazivima u mnogim slučajevima može tek uvjetno koristiti, jer se neke partijce nije moglo jasno ukalupiti, a i mišljenja i stavovi nisu bili nepromjenjivi. Tako su izvještaji o Mikulićevu ponašanju i istupima („nacionalističkim ispadima“, piše Kufrin) došli do viših partijskih instancija, no Mikulić nije sankcioniran jer ga je, po svemu sudeći, štitio Pirker. ${ }^{14}$

Jedan od sukoba, o kojemu je pisala i Kufrin, dogodio se između Mikulića i načelnika Stanice javne sigurnosti, koji nije bio Mikulićev istomišljenik, a k tome je bio i Srbin. Situacija je okončana tako što je Mikuliću pošlo za rukom ishoditi smjenjivanje spomenutoga i instalirati ljude od svojega povjerenja. ${ }^{15}$ Ovdje treba spomenuti da se u to vrijeme kao jedna od važnijih tema nametnulo pitanje kadrova u vojsci, policiji i raznim državnim službama s obzirom na nacionalnost

14 HDA dosje 248 494: 1, 29, 31, 33-34, 215, 236, 244-245.

15

Isto: 4,32 . 
jer su u javnost dolazili podaci, a mnogima je iz prve ruke bilo poznato da u nizu državnih službi u SRH neproporcionalno udjelu u stanovništvu, kako se to pitanje postavljalo, dominiraju Srbi. Kada je riječ o ovim kadrovskim promjenama, Mikulić je radio na lokalnoj razini istu stvar koju je reformno orijentirani dio vrha hrvatske Partije i vlasti nastojao činiti na višim razinama. Tu je dolazilo do velikih otpora i sukoba kada bi se stare, partizanske borce, koji su se teško nosili s promjenama u gospodarstvu i drugim granama, nastojalo zamjeniti školovanim, mlađim kadrovima. O tome je opširno Dabčević-Kučar pisala u svojoj knjizi.

Kufrin, pak, dodaje da je potez izazvao niz reakcija i da je zaprimila mnoge upite u kojima je stajalo je li do smjenjivanja došlo isključivo na nacionalnoj osnovi. Argumenata za takvu ocjenu ipak je bilo jer je u obrazloženju prijedloga za smjenjivanje, pored partijske odgovornosti za jedan čin (isticanje zastave SR Srbije na jednoj proslavi), Mikulić istaknuo kako Jaska kao dominantno hrvatski kraj ne može imati Srbina za načelnika SJS-a. ${ }^{16}$ Sužavajući pitanje kadrova na zastupljenost Srba u državnim službama, takvih je primjera zaista bilo, kako na republičkoj razini (u miliciji, recimo) tako i na saveznoj (posebno vojska i diplomacija). Reformska struja u CK SKH dopustila je stanovitu javnu raspravu o tome problemu, pa i sama govorila o tome (poput Tripala). Druga strana u CK-u zamjerala je potonjoj javno postavljanje toga pitanja, ujedno izbjegavajući raspravu o njemu. A Srbi u Hrvatskoj, u nizu sredina izloženi prebrojavanju, počeli su se osjećati ugroženo. ${ }^{17} \mathrm{Zbog}$ činjenice da je ovakva situacija postojala u jednopartijskoj diktaturi, koja nije dopuštala slobodnu raspravu o tim i sličnim problemima, dolaskom nešto prostora za tek donekle otvorenije izjašnjavanje, ovo je pitanje u nekim slučajevima dobilo i negativnu, nacionalističku komponentu. Bila je to posljedica godinama nagomilavanih trauma, nezadovoljstva i frustracija. Treba kazati i to kako je natprosječna zastupljenost Srba u Hrvatskoj u nekim službama bila posljedica Drugog svjetskog rata, tj. visokog postotka Srba u partizanskom pokretu u Hrvatskoj.

Pored gore prezentiranog slučaja, pribavljen je niz iskaza koji su govorili o Mikulićevim provokacijama i svađama s osobama srpske nacionalnosti, pa čak i o jednom fizičkom obračunu. Među svjedocima bilo je i Hrvata, recimo, osoba koje su svjedočile navodnim incidentima u ugostiteljskim objektima, ali i Srba, koji su bili predmet napada, a najčešće se radilo o pripadnicima vojske i milicije. Nakon promjena u hrvatskom partijskom i državnom vrhu te padanja Mikulića i njegovih istomišljenika na lokalnoj razini u nemilost režima, može se pretpostaviti da se među optužbama našlo i izmišljenih elemenata. No, s druge strane, $s$ obzirom na opisano nezadovoljstvo i frustriranost općenitim položajem Hrvatske u Jugoslaviji, ne samo nacionalnim sastavom kadra u državnim službama (bilo

HDA dosje 248 494: 4, 31-32; DABČEVIĆ-KUČAR 1997: 57, 92, 104, 116, 324-327.

17 RADELIĆ 2008: 392-400. 
ono opravdano i imalo realna utemeljenja ili neopravdano, bazirano prvenstveno na nacionalnoj netrpeljivosti), te Mikulićevu narav koja je u nekim situacijama znala biti nagla i eksplozivna (o čemu govori niz raznih izvora iz razdoblja njegova boravka u političkoj emigraciji), valja generalno zaključiti da je Mikulić u takve sukobe ulazio i da ih je u nekim slučajevima i izazivao i poticao. U ovome kontekstu, neki su svjedoci kazali kako je u jednom navratu govorio da su Srbi u Hrvatskoj manjina i da bi se u skladu s time trebali i ponašati. Za razumijevanje ovakvih istupanja nužno je dodati i kako su Srbi u SRH prema Ustavu imali položaj konstitutivnog naroda, a ne manjine. Dabčević-Kučar je u svojoj knjizi zapisala da je to bio „ustupak za koji smo se dogovorili“, s obzirom na ulogu srpskog naroda u partizanskom ratu, stoljetnu povezanost dvaju naroda na istome području i činjenicu da su Srbi bili najbrojnija manjina u Hrvatskoj. Međutim, ona iznosi i kako se djelomično radilo i o pritisku vlasti u Beogradu. S druge strane, naglašava da je politika reformnog dijela rukovodstva išla za pridobivanjem hrvatskih Srba, usporedno $\mathrm{s}$ time što se nastojalo donekle promijeniti njihovu prezastupljenost $\mathrm{u}$ nekim državnim službama, što je trebalo na koncu dovesti do većeg povjerenja između dvaju naroda. Isto tako, neki su tvrdili da je Mikulić provjeravao kako se tko izjasnio po nacionalnosti na popisu stanovništva 1971. godine, s obzirom na prisutnost grkokatolika na Žumberku. Jednu je osobu navodno i verbalno napao zato što se izjasnila kao Jugoslaven. ${ }^{18}$

Smijenjeni je načelnik milicije u svojoj izjavi s početka 1972. godine tvrdio kako je Mikulić u Japetiću povodom 30 godina od izbijanja narodnog ustanka govorio da je razbio Partiju i policiju te da mu još preostaje vojni garniznon. Dodao je kako vojska u garnizonu ima oružje, no imaju ga i njegovi ljudi u teritorijalnim jedinicama. Branko Pasecki, tada predsjednik Socijalističkog saveza radnog naroda, jednom je prigodom kazao da bi se te jedinice morale ojačati protutenkovskim oružjem. Kufrin je zapisala da se Mikulić posebno bavio dobrovoljnim vatrogasnim društvima na području Općine, koja su bila disciplinirana, ustrojena po poluvojničkom modelu. Tako je izdvojio velika novčana sredstva za kupnju deset kombija. Još jedna od stvari koja se Mikuliću stavljala na teret, zajedno s Paseckim, bila je potpora koju su pružali Akademskom klubu iz Jastrebarskog. Naime, Klub je osnovan 1964. godine, a neki njegovi članovi bili su osuđeni na zatvorske kazne zbog članstva u ilegalnoj organizaciji, najvećim dijelom sastavljenoj od studenata - Hrvatskom oslobodilačkom pokretu. Pasecki i Mikulić navodno su Klubu pružali moralnu podršku i davali materijalnu pomoć, a dio članova podupirao ih je u provođenju ,političkih ciljeva masovnog pokreta“. Kasnije je Mikulić navodno govorio kako je Maspok u Jastrebarskom počeo i prije poznate

18 HDA dosje 248 494: 7-10, 13, 18-21. Za ponašanje Mikulića u emigraciji vidi, primjerice, ostatak njegova dosjea. DABČEVIĆ-KUČAR 1997: 313, 318, 324. Za širi pogled na tu problematiku vidi u istoj knjizi dio od 306 do 349. 
Desete sjednice CK SKH, koja je održana početkom 1970. godine, a na kojoj je inagurirana nova, reformistička politika.

Daleko upečatljiviji događaj bilo je održavanje sastanaka krajem 1969. i početkom 1970. godine, uglavnom u Desincu, a na kojima se raspravljalo o potrebi osnivanja Hrvatske gospodarske banke. Domaćin je bio Mikulić, a prisustvovala su neka od istaknutijih imena reformnog pokreta. Tu se našao Većeslav Holjevac, znameniti zagrebački gradonačelnik, jedan od istaknutih pripadnika partizanskog pokreta u Hrvatskoj i u to vrijeme osoba u stanovitoj nemilosti režima, zatim Marko Veselica i Šime Đodan, vatreni i u javnosti iznimno istaknuti pobornici teze prema kojoj je Hrvatsku gospodarski iskorištavao Beograd. Sudjelovali su još neki, poput Markova brata, doktora ekonomije Vlade Veselice ili Hrvoja Šošića, koji je na jednom studentskom skupu iznio ideju da bi Hrvatska, po uzoru na sovjetske republike Ukrajinu i Bjelorusiju, trebala dobiti mjesto u Ujedinjenim narodima. Mikulić je na ispitivanju rekao da je prisustvovalo još između deset i petnaest direktora tvrtki, koje su trebale osigurati kapital za osnivanje banke. Osnovna namjera okupljenih bila je da se tako pokuša spriječiti daljnje odlijevanje novčanih sredstava koje je zarađivalo hrvatsko gospodarstvo u Beograd te da se ona investiraju u Hrvatskoj, što se, prema njihovu mišljenju, događalo i što je kočilo Hrvatsku u njezinu napretku. Namjeravao se izdati i poziv brojnim hrvatskim iseljenicima da ulažu svoja sredstva zarađena u inozemstvu u tu banku. ${ }^{19}$ Spomenuti sastanci jedan su od pokazatelja kako se Mikulić nije zadržao na pukom poznanstvu ili prijateljstvu s nekima od najistaknutijih pobornika reformnog pokreta, nego da je sudjelovao u kreiranju nekih važnih zamisli i projekata, odnosno da se nije zadržao samo na djelovanju na lokalnoj razini.

Gospodarska pitanja unutar reformnog pokreta bila su jedna od najčešćih tema koje su se javljale u javnosti u to vrijeme. U Hrvatskoj su neki elementi pokreta snažnije (spomenuti Veselica ili Šošić, a i studentski je štrajk počeo zahtjevima za stanovitim promjenama u gospodarskim odnosima Zagreba i saveznog centra), a drugi u nešto blažoj formi zastupali tezu kako se Hrvatsku iskorištavalo na nizu polja (recimo, u pitanju prema zarađenim devizama ili reguliranju vanjske trgovine). U potonju skupinu treba ubrojiti i Dabčević-Kučar, koja je godinama kasnije, $\mathrm{u}$ autobiografskome radu bila prilično oštra, pišući da se u nekim područjima radilo o „pljački hrvatskog gospodarstva“, a u drugima da je bilo „riječ o tipu kolonijalne eksploatacije“. ${ }^{20}$ Da se radilo o vrlo kompleksnom pitanju, vidi se u slaganju povjesničara Ive Goldsteina s kasnije istaknutim komunističkim prvakom Stipom Šuvarom, koji je nakon sloma reformnog pokreta napisao da su se sve republike u dužem periodu podjednako razvijale. Štoviše, postojali su pokazatelji koji su sugerirali da su se razvijenije republike razvijale brže. ${ }^{21}$

\footnotetext{
HDA dosje 248 494: 2-3, 29, 32.

20 DABČEVIĆ-KUČAR 1997: 19, 275.

21 GOLDSTEIN 2008: 541.
} 
Sljedeći primjer odnosi se na Mikulićevo sudjelovanje u raspravama o još jednoj temi koja je zaokupljala pozornost političkih elita i javnosti tijekom reformnog pokreta, a riječ je o pitanju masovnog iseljavanja iz Socijalističke Republike Hrvatske. Naime, tijekom šezdesetih velik broj građana napustio je SRH i otišao na tzv. privremeni rad u zapadnoeuropske zemlje, koji se u brojnim slučajevima pretvarao u stalni ostanak u inozemstvu. Nešto prije sastanaka na kojima se raspravljalo o osnivanju Hrvatske gospodarske banke, u listopadu 1969. godine održano je okupljanje na kojem su prisustvovali Mikulić, Pasecki, zatim Josip Šentija, tada dopisnik Vjesnika i izvjestitelj Radio-televizije Zagreb iz Italije, a potom član Izvršnog vijeća Sabora te Zvonimir Komarica, preživjeli iz ustaškog zatvora Kerestinec, član partizanskog pokreta, koji je imao uspješnu diplomatsku karijeru, a bio je i član Upravnog odbora Matice hrvatske i predsjednik Komisije za veze s Hrvatima u svijetu. Bilo je tu još nekih, poput Andrije Klarića, bivšeg konzula u Njemačkoj, jednog od vrlo rijetkih Hrvata u tadašnjim jugoslavenskim diplomatskim ispostavama. Prema dokumentima iz dosjea, razgovaralo se o hrvatskoj državi i državnosti, „neravnopravnom“ položaju Hrvatske u Jugoslaviji, „vjekovnoj potlačenosti“ Hrvata, neravnomjernom rasporedu diplomatskih kadrova po nacionalnom ključu, navodnom potiskivanju hrvatskog književnog jezika te mogućnostima za ponovno postavljanje spomenika banu Jelačiću. Iste, 1969. godine, Mikulić je nazočio otkrivanju jedne biste u Donjoj Kupčini, pri čemu je kazao da za njega SKJ i SKH ,ništa ne znače“. Svjedok je tome dodao: „Mikulić je u prvi plan stavljao socijal-demokratske partije kakve su danas na Zapadu“. Kazao je k tomu kako je Mikulić tog istog dana u jednom selu na zabavi pjevao Ustani bane i Još Hrvatska ni propala, kao i druge „,nacionalističke“ pjesme.22

Opravdano se može postaviti pitanje jesu li potonji događaji izmišljeni ili preuveličani. Iako je nemoguće odgovoriti sa stopostotnom sigurnošću, s obzirom na ostale podatke o Mikulićevu istupanju u promatranome periodu te njegovo djelovanje u političkoj emigraciji, može se pretpostaviti kako je sukus opisa ovih događaja točan. Govoreći o isključenju Đodana i Veselice iz SKH, Dabčević-Kučar događaj je objasnila kako su oni sami svojim izjavama negirali ,pripadnost komunizmu““. ${ }^{23}$ I Mikulić bi se, na temelju iznesenih izjava, mogao svrstati u skupinu takvih, tada očito u njihovim privatnim, a sve više i javnim istupima, bivših članova SKH.

$\mathrm{Na}$ tome tragu treba konzultirati i izvještaj Milke Kufrin o proslavi obljetnice ustanka u Jaski krajem svibnja 1971. godine. Ne samo da na proslavu nisu bili pozvani članovi lokalnog komiteta Partije, Saveza boraca ili, pak, predstavnici susjednih općina Vrginmost i Vojnić, nego je Pasecki čak bio protiv toga da se stavi Titova slika na tribinu, što je na kraju ipak učinjeno, ali na slabije vidljivo mjesto.

$22 \quad$ HDA dosje 248 494: 2-3, 29, 32, 36, 53, 152.

23 DABČEVIĆ-KUČAR 1997: 627. 
O tome je Kufrin napisala: „Postupak s Titovom slikom pokazao je da je taj pokret antikomunistički i nacionalistički““. ${ }^{24}$ Sljedeći događaj u ovome svjetlu vezan je uz osnivanje Ogranka Matice hrvatske u Jastrebarskom, čiji je predsjednik postao Mikulić. Tom je prilikom navodno kazao da mu je izbor za predsjednika Ogranka Matice hrvatske draži od onoga za predsjednika općinske skupštine, a učlanjenje u Maticu draže od učlanjenja u Savez komunista. ${ }^{25}$ Pored izjava kojima se Mikulića udaljavao od Partije, zabilježene su i one u kojima se vidjelo da se jugoslavenskim okvirom više ne koristi kao referentnim u svojim govorima. Na proslavi Dana borca u Klinča Selu, Mikulić je navodno naglasio slušateljima da se trebaju ponositi time što su Hrvati i da to ne smiju nikada zaboraviti. Jedan je svjedok uočio kako Mikulić nije govorio da bi se Hrvatska trebala razvijati u sklopu Jugoslavije. ${ }^{26}$

Nakon sloma reformnog pokreta, službeni su organi govorili o tzv. emisarima, koji su obilazili dijelove Hrvatske i širili „nacionalizam“ te ideje Maspoka. To se ponajčešće odnosilo na različita predavanja, predstave i manifestacije. Jedan je svjedok tvrdio kako su Mikulić i Pasecki organizirali dolazak emisara na područje Općine, poput Franje Tuđmana, Veselice, Đodana ili, pak, Slobodana Budaka, javnog tužitelja koji je podnio ostavku, ne želeći sudjelovati u političkim procesima protiv sudionika reformnog pokreta. Janko Bobetko, tada saborski zastupnik i zamjenik komandanta Zagrebačke vojne oblasti, bio je također blizak s Mikulićem. Bobetkov pretpostavljeni bio je Đoko Jovanić, a neki su svjedoci tvrdili kako je Mikulić govorio da će Bobetko doći na njegovo mjesto. Kufrin je prenijela kako je Mikulić u više navrata govorio da je Bobetko budući zapovjednik hrvatske vojske. ${ }^{27}$ Pribavila je podatke i o tome da je Bobetko jednom saborskom zastupniku govorio kako podržava Mikulićeve poteze. Isto tako, Mikulić je na jednome sastanku u Svetoj Jani govorio da će Budak biti republički sekretar za unutrašnje poslove. ${ }^{28}$ Sve su ovo daljnji dokazi Mikulićevih nastojanja i želja da na lokalnoj, ali i državnoj razini sudjeluje u kadrovskim izmjenama, a u kontekstu tadašnjih nadmetanja dviju struja unutar hrvatske Partije.

\section{„Sjećanja na Hrvatsko proljeće“ Franje Mikulića}

Nakon dvogodišnjeg mandata predsjednika Sabora HNV-a, Mikulićeva je politička karijera u inozemstvu krenula silaznom putanjom, a na koncu je 1981.

\footnotetext{
$24 \quad$ HDA dosje 248 494: 37-38.

25 Isto: 3,12 .

26 Isto: 5.

27 Bobetko na koncu nije došao na čelo Pete vojne oblasti, već je nakon sloma reformnog pokreta smijenjen s dužnosti. No, tijekom većeg dijela Domovinskog rata vršio je dužnost načelnika Glavnog stožera Oružanih snaga Republike Hrvatske, tako da su se ove Mikulićeve prognoze u konačnici zapravo i ostvarile.

28 HDA dosje 248 494: 3, 6, 10, 35-36.
} 
godine u Saveznoj Republici Njemačkoj osuđen na zatvorsku kaznu. Nije dočekao izlazak na slobodu, preminuvši u zatvoru u travnju 1983. godine. ${ }^{29}$ Mikulić je robijaške dane odlučio kratiti i pisanjem svojevrsnih memoara, u kojima je središnji dio, kako im je i naslov kazivao, zauzimalo Hrvatsko proljeće. To je najveći tekst (točnije, zbirka tekstova) koji je o toj problematici objavio neki proljećar u emigraciji, ali ujedno i najopširniji tekst ove tematike koji se u emigraciji pojavio. Iz uvodnoga dijela jasno je kako se ističe i po svojoj kronološkoj odrednici, tj. da se pojavio desetak godina prije sličnih istupa i djela u Hrvatskoj. Naime, Hrvatski tjednik iz Australije, neslužbeno glasilo Hrvatskog državotvornog pokreta, tijekom 1981. i 1982. godine objavio je Mikulićev tekst u sedamnaest nastavaka. Ovaj bi izvor trebalo smatrati vrijednim svjedočanstvom o hrvatskom reformnom pokretu i zato što je o najvećem broju njegovih tema Mikulić govorio ne sa željom postizanja nekog trenutnog političkog cilja, već s nekim drugim motivima. Svjedočenje je

$29 \quad$ Nakon izbora za Drugi sabor HNV-a postavljeno je pitanje razdiobe službi među tridesetoricom izabranih sabornika. Dio osoba s dužim emigrantskim stažem predlagao je da se nakon sloma reformnog pokreta mora pokazati političko jedinstvo Hrvata, odnosno da Hrvati s cijelog političkog spektra, od desnice, preko centra, pa onda i ljevice, jednodušno stoje na potrebi stvaranja samostalne hrvatske države. Naime, nasilno gušenje reformnog pokreta ocjenjivalo se kao kolaps nada dijela hrvatskih komunista i ljevičara u mogućnost postojanja Jugoslavije koja nudi jednake mogućnosti za razvoj svim narodima u njoj. Stoga bi sudjelovanje jednog bivšeg jugoslavenskog partijskog funkcionera u tijelu u kojem su se, osim mlađih emigranata antikomunista, nalazile i osobe koje su na razne načine bile angažirane u NDH, nosilo snažnu poruku o prevladavanju teških ideoloških podjela među Hrvatima i susret na zajedničkom nazivniku - ideji samostalne hrvatske države. Tako je Mikulić izabran za predsjednika Sabora HNV-a, a i ostala trojica proljećara koja su ušla u Sabor (Bruno Bušić, Zlatko Markus i Tomislav Mičić) dobila su važne pozicije. Mikulić je u tome svojstvu obišao mnogo hrvatskih kolonija diljem svijeta. Bio je vičan nastupu pred masama pa su ga nazivali i pučkim tribunom. S druge, pak, strane, objektivno gledajući, u nekim aspektima nije uspjevao ispuniti sva očekivanja koja su se pred njega postavljala kao predsjednika, poput stvaranja veza sa stranim političarima, novinarima i slično. Neki su držali kako ga i njegov privatni život sputava u boljem obnašanju predsjedničke funkcije. HNV je koncem sedamdesetih zahvatio sukob između dviju struja, od kojih je jedna zagovarala nenasilne metode djelovanja i oslonac na države Zapada s demokratskim uređenjem, a druga primjenu svih metoda u antijugoslavenskom djelovanju, uključujući oružje, te dopuštala potencijalno traženje savezništava i izvan zapadnog bloka, za koji su držali kako će i dalje nastavljati podržavati opstanak Jugoslavije. Mikulić je pripadao potonjoj grupaciji. U tome turbulentom razdoblju zbio se i navodni pokušaj otmice Mikulića. On i njegovi pristaše tvrdili su kako je iza toga stajala Jugoslavija, dok su drugi kontrirali, govoreći kako je do okršaja došlo zbog nekih Mikulićevih privatnih stvari. Tada je došlo i do raskola u HNV-u i osnivanja nove organizacije - Hrvatskog državotvornog pokreta. Mikulić nije uspio znatnije sudjelovati u njezinu radu jer je dospio u zatvor zbog sudjelovanja u jednome obračunu s vatrenim oružjem. Kao i u drugim sličnim i brojnim događajima u koje su bili involvirani politički emigranti, javljale su se glasine kako se radilo o svađi privatnog karaktera, koja je eskalirala, dok su drugi tvrdili da je Mikulić bio izazvan od suradnika jugoslavenske i njemačke policije, s obzirom na to da su ga i Jugoslavija i Savezna Republika Njemačka na bilo koji način nastojale onemogućiti u njegovu radu. Historiografski radovi o opisanoj problematici ne postoje, a autor je napisao ovaj kratki prikaz nakon pregledavanja velikog broja dosjea hrvatskih političkih emigranata, časopisa i novina koje su izdavali i njihove privatne korespodencije, kao što je i neke još uvijek žive sudionike tih događaja intervjuirao. O nekima od spomenutih događaja vidi u ostatku Mikulićeva dosjea. 
neka vrsta ispovijedi, priče čovjeka koji je svjestan da je najvjerojatnije došao do kraja svog političkog puta. Kao što se ubrzo pokazalo, i do kraja životnoga puta. Sve te za njega teške okolnosti mogle su utjecati na razinu iskrenosti njegovih riječi. Mikulić se nakon izlaska iz zatvora više nije mogao nadati položaju u emigraciji kakav je imao kao predsjednik Sabora HNV-a. Dakako, bio je svjestan da više nikada neće imati političku moć i utjecaj kakav je imao u domovini u vrijeme reformnog pokreta. U Mikulićevim riječima nema nikakve mržnje prema političkim protivnicima u emigraciji. Dapače, i sâm se posipa pepelom, ustvrđujući kako se nije snašao u političkoj emigraciji. Sve ove činjenice govore u prilog tezi da je velik dio teksta pokušao oblikovati sine ira. Tu je neophodno podcrtati da većinu osoba nije slikao u isključivo tamnim i isključivo svijetlim tonovima. $U$ odsutnosti pokušaja da osvrtom na proljećarska zbivanja argumentira neko svoje razmišljanje o aktualnostima, Mikulić je progovorio o raznim osobama koje nisu bile poznate široj javnosti u Hrvatskoj, a potpuno nepoznate političkoj emigraciji. Takvi su reci posebno vrijedni i zanimljivi. Interesantan je i niz crtica vezanih uz poteze i nekih istaknutijih osoba iz tog perioda, a o kojima se nigdje nije moglo čitati, i koje, doduše, velikim dijelom nije moguće provjeriti. U daljnjem tekstu pozornost će se usmjeriti upravo na prethodno istaknute teme. Naravno, njegovim je uspomenama i dalje potrebno prilaziti sa znatnom dozom kritike.

Prva je dva nastavka Mikulić posvetio dvjema osobama koje je vrlo cijenio. Radi se o Većeslavu Holjevcu, s kojim je njegovao i bliske prijateljske odnose, te generalu Ivanu Rukavini. Mikulić je prvoga označio kao onoga koji ga je „uputio u pravo stanje našeg naroda u tzv. zbratimljenoj Jugoslaviji“. Osim toga, prema Mikuliću, Holjevac je pomogao mnogima da se nađu „na strani pravedne borbe hrvatskog naroda" te je navodno govorio da je komunistička Jugoslavija lošija za Hrvate od one kraljevske. U kapitalne stvari koje je Holjevac napravio, ubrojio je napredak koji je Zagreb doživio dok mu je spomenuti bio na čelu te nastojanja da spriječi ili barem smanji izvlačenje sredstava iz grada u budžet federacije. O događajima uz osnivanje kasnije poznatog zagrebačkog Velesajma Mikulić je ponudio dosad nepoznate i daljnjih eventualnih istraživanja vrijedne detalje. Kazao je kako su postojale želje da se Velesajam prebaci u Beograd pa su s tim ciljem postavljeni uvjeti da mora biti završen u nemoguće kratkom roku ili će se u protivnome seliti. Da stvar bude još i teža, nedostajalo je sredstava pa je Holjevac navodno pokucao na vrata uspješnim privrednim organizacijama u Zagrebu i izvan njega, koje su unaprijed zakupile i platile izložbeni prostor, što je bilo presudno za dovršenje gradnje. Ipak, i dalje je postojao problem namjerno prekratkih rokova, no Holjevac je i tome problemu doskočio, uz pomoć Rukavine, koji je poslao vojnike Pete vojne oblasti da na nekoliko dana i noći blokiraju Velesajam i bacačima plamena suše žbuku. ${ }^{30}$ Potonja je zgoda zaista zanimljiva,

30 Sjećanja na Hrvatsko proljeće, Hrvatski tjednik, 1. 12. 1981., 18. 
ali i teško provjerljiva. Isto tako, može se domišljati na koje se sve konkretne načine Holjevac pokušao othrvati pritiscima da se velesajam preseli u Beograd, no važno je istaknuti kako se zaista suprotstavljao nekim oblicima centralizacije. ${ }^{31}$

Na položaju predsjednika Matice iseljenika Holjevac je, prema Mikuliću, postigao „izvanredne“ rezultate, koji su se mogli prekinuti jedino njegovom smjenom, što se i dogodilo. No, Holjevac se nakon toga snažnije angažirao u Matici hrvatskoj. Njegov se pad na hijerarhijskoj ljestivici režima nastavio pa je ubrzo smijenjen sa svih dužnosti povodom objavljivanja poznate Deklaracije o nazivu i položaju hrvatskog književnog jezika, koja je izazvala političke potrese ne samo u Hrvatskoj nego i u Jugoslaviji. Iako nije potpisao dokument, Mikulić tvrdi da su se gotovo svi potpisnici konzultirali s njime u vezi s time. Nije se želio javno pokajati, niti tražiti da se netko zauzme za njega. Mikuliću je u Planinarskom domu u Japetiću kazao kako ne želi da ga se štiti jer će „brutalan postupak velikosrba i unitarista prema njemu, koji je neosporno bio najveća legenda partizanskog rata u Hrvatskoj, pa i Jugoslaviji, otvoriti oči onima u zarobljenoj Hrvatskoj, jer će si mnogi morati postaviti pitanje što mogu očekivati oni, ako se ovako postupa s Holjevcem“. Pokazalo se da je imao pravo, naglasio je Mikulić. Potonji je Holjevca zatim počeo pozivati na javne skupove u Jastrebarskom, a to su činili i ostali diljem Hrvatske. Na Holjevčevu sprovodu susreo je i Tuđmana, kojom su prilikom obojica jedan drugoga upitala „kako dalje“. Time je očito želio naglasiti Holjevčevu važnost u disidentskoj grupi koja se stvarala u dijelu hrvatske partijske i nepartijske inteligencije. Na kraju dijela o Holjevcu Mikulić je napisao da je prisustvovao skupovima na kojima su bili Tuđman, Đodan, Veselica, Gotovac i Vlado Mutak, a Holjevac im je davao ton i usmjeravao rasprave. ${ }^{32}$

I u Rukavininu je slučaju Mikulić ponudio niz komplimenata na račun tog visokog oficira jugoslavenske vojske, koji je bio član Partije od 1935. godine; kao dobrovoljac sudjelovao je u Španjolskom građanskom ratu, a za vrijeme Drugog svjetskog rata vršio je neke od najviših vojnih dužnosti (npr. zapovjednik Glavnog štaba Hrvatske). Među ostalim, ocijenio ga je kao intelektualca sklonog dogovoru i kompromisima. Mikulić je istaknuo da se Rukavina izjašnjavao Hrvatom, a ne Jugoslavenom, što mu se u Beogradu zamjeralo. Može se pretpostaviti da je ova konstatacija točna, s obzirom na to da je vojska bila jedan od stupova države te je u njoj i sličnim institucijama bilo poželjno, pogotovo na najvišim razinama, izabirati prvenstveno jugoslavenski identitet. Mikulić je dalje naveo da je iz Rukavinine poslijeratne karijere najviše ostao upamćen njegov rad na koncepciji teritorijalne obrane te zalaganje za domicilno služenje vojnog roka u regularnoj vojsci, što je tek djelomično točno. ${ }^{33}$ Bliskost s reformskom strujom u Partiji naštetila mu je

\footnotetext{
31 GOLDSTEIN 2008: 492.

32 Sjećanja na Hrvatsko proljeće, Hrvatski tjednik, 1. 12. 1981., 18.

33 O historiografskoj analizi tih pitanja vidi: GOLDSTEIN 1985: 141-157.
} 
u karijeri, o čemu Mikulić ponovno nudi detalje, pišući da je promaknut u viši čin prilikom smjenjivanja s dužnosti zapovjednika Pete vojne oblasti, no time je izgubio kontrolu nad jedinicama. Nakon Karađorđeva skupljali su se potpisi zaslužnih boraca i revolucionara kao potpora Titu te se očekivalo da se i Rukavinin nađe na njemu, no on je izostao. ${ }^{34}$

Plejadu visokih jugoslavenskih oficira hrvatske nacionalnosti Mikulić je nastavio s Bobetkom, koji je tada bio načelnik štaba Pete armije, a budući da je u Jastrebarskom bio smješten jedan od tenkovskih garnizona, Bobetko je u obilasku i njega posjećivao. Mikulić je napisao da su se dobro slagali, zatim kako je Bobetko bio strog, ali pravedan te da mu je on prvi rekao da u časničkom kadru Pete armije navodno ima samo 6\% Hrvata. Razgovaralo se o modalitetima kako to stanje promijeniti, a Bobetko se uzdao u Titovu potporu i zaštitu na tome putu. No, slom reformnog pokreta pogodio je i Bobetka, što je, prema Mikuliću, ponukalo Bobetkovu majku da vrati ordene narodnog heroja za poginulog supruga i dvojicu poginulih sinova. Mikulić je u vezi s time istaknuo da je jedna hrabra starica tako pljunula na „NOB“. (Narodnooslobodilačka borba, op. a.). ${ }^{35}$

U ovome je kontekstu Mikulić pisao kako je došlo do sukoba njega i spomenutog Đoke Jovanića oko izbora komandanta garnizona u Jastrebarskom. Na koncu je Mikuliću pošlo za rukom, uz Bobetkovu pomoć, da se na to mjesto imenuje Hrvat Drago Radoš. Mikulić je spomenuo i poznanstvo s generalom-potpukovnikom Vladom Mutkom, koji je bio predsjednik Nogometnog kluba Zagreb, a Mikulić potpredsjednik. Prema Mikuliću, Mutak je pripovijedao kako je u partizane otišao želeći se boriti za nacionalno oslobođenje i da klasna komponenta u njega nikada neće imati prednost pred nacionalnim. Govoreći o ovoj tematici, Mikulić je opisivao na kakve je sve poteškoće nailazio u revalorizaciji uloge Hrvata u partizanskom pokretu. I neki su drugi intelektualci vodili bitke na tome području, poput Franje Tuđmana.

Pandane spomenutih oficira u civilnome životu Mikulić je na neki način pronašao u osobama republičkog tužitelja Ljudevita Dežmana i tužitelja Grada Zagreba Slobodana Budaka. Tvrdio je kako je i njih poznavao, što za Budaka npr. potvrđuju i navodi iz Mikulićeva dosjea, kao što je slučaj i s osobama iz prethodnog odlomka. Pišući o spomenutim osobama, Mikulić je ponovno progovorio o važnosti hrvatskih partizana, navodeći kako je Dežman bio jedan od učenika koji su na maksimirskom stadionu prišli Židovima, odnosno Srbima, kada ih je ustaški režim nastojao podijeliti i razdvojiti, dok je kasnije otišao u partizane. Budak, čiji je otac bio ugledni komunist, bio je zaslužan što je iz tiska izašla poznata Šegedinova knjiga Svi smo odgovorni (Mikulić je naveo da je bio prisutan kada su Budak i još nekolicina ljudi o tome razgovarali). Naime,

\footnotetext{
34 Sjećanja na Hrvatsko proljeće, Hrvatski tjednik, 1. 12. 1981., 18; 8. 12. 1981., 15.

35 Isto, 23. 2. 1982., 17.
} 
Tripalo i Dabčević-Kučar navodno su savjetovali da još nije vrijeme za izlazak takve knjige. ${ }^{36}$

Treća se tema odnosi na još jedno Mikulićevo iskustvo, ono ekonomske problematike, a radi se o Agrokombinatu. I tu je kao jednu od čelnih osoba, uz Antu Todorića i Ota Krkvarića, istaknuo Holjevca, podcrtavajući nastojanja čelništva ove tvrtke da joj se dade hrvatski nacionalni karakter. Mnogi su zaposlenici i stručnjaci bili i „,hrvatski orijentirani“, a osnovan je ogranak Matice. „Neprijatelji“ su uvidjeli što znači velika i uspješna tvrtka u rukama „hrvatski nastrojenih ljudi“ te su raznim „podvalama“ željeli smijeniti rukovodstvo, stoga je Mikulić 1969. godine morao otići. O Anti Todoriću pisao je kao o iznimno sposobnom čovjeku, koji je nakon sloma reformnog pokreta osuđen na zatvorsku kaznu. ${ }^{37}$ Mikulić je u ovome dijelu pisao i o navodnim načinima izvlačenja novca iz Hrvatske, prodajom, odnosno kupnjom deviznih sredstava od Beograda po nepovoljnom tečaju. No, i to pitanje valja promatrati u kontekstu već iznesene rasprave o međusobnim ekonomskim odnosima republika, odnosno republika i federacije.

Prikladno za ovaj rad i njegove komparacije, a govoreći i dalje o ekonomskim temama, Mikulić je opisao svoje kontakte s Milkom Kufrin-Bulat, zastupnicom Općine Jastrebarsko u Saboru. Prema njegovu mišljenju, imala je dosta negativnih, ali i nekoliko pozitivnih strana jer je bila vrlo uporna i mnogo radila. Satima su razgovarali, pri čemu ona nije skrivala hrvatsko podrijetlo, no uvijek je naglašavala potrebu „bratstva i jedinstva“, napisao je Mikulić. U njegovim očima u pozitivne osobine očito joj je ubrojio to da je kao predsjednica Saveznog komiteta za turizam došla u sukob s unitarističkim strukturama, koje su veći dio novca usmjerile na kontinentalni turizam, pa se vratila na tu funkciju na republičkoj razini i uopće nije skrivala razloge tog postupka. Navodno mu je govorila i o raznim podvalama koje su joj činili dok je bila u Beogradu. Često se događa da se razlike između dviju struja unutar vrha SKH svode tek na politička shvaćanja, no zaboravlja se da su na te odnose utjecali i neki drugi faktori, poput doživljaja stanovitog pojedinca o nečijem karakteru, ponašanju ili potezima koji nisu bili izravno vezani uz pitanja daljnjeg pravca politike SKH. Stoga se može iznesti informacija koju je ponudio Mikulić, a koja govori da je došlo do osobnog sukoba između Kufrin-Bulat i Dabčević-Kučar. Iako nije istupio otvoreno, proizlazi da je Mikulić na neki način dao za pravo Kufrin, dodajući da je „zamrzila“ DabčevićKučar nakon toga incidenta. ${ }^{38}$

Mikulić se osvrnuo i na Radu Bulata, Milkina supruga, kojega je također poznavao i susretao se s njime. Bulat se, napisao je Mikulić, vratio zajedno sa suprugom iz Beograda i postao komandant zagrebačkog vojnog područja. Tada je

$36 \quad$ Isto, 9. 3. 1982., 17.

37 Isto, 18. 12. 1981., 13-14.

38 Isto, 16. 2. 1982., 15. 
bio general-potpukovnik i protivnik unitarizma, no nije se u svemu slagao s Holjevcem. Želio je doći na Rukavinino mjesto, no kada mu to nije uspjelo, povukao se iz vojske. Mikulić je smatrao da bi ga kao „hrvatskog pravoslavca“ i protivnika unitarizma trebalo nagraditi nekom važnijom pozicijom, o čemu je razgovarao s Pirkerom i Tripalom. Imenovan je za sekretara komisije za Narodnu obranu u CK-u, a Dušan Dragosavac, Milutin Baltić, Čedo Grbić i neki drugi „manje prihvatljivi“ ostali su na višim funkcijama, što ga je revoltiralo te je „otplovio u otvorene velikosrpske vode“. ${ }^{39}$

Poznanstvo s još nekim osobama iz hrvatskog komunističkog vrha rezultiralo je njihovim plastičnijim opisom u odnosu na one koje su producirali stariji politički emigranti, koji su u najvećem broju bili jednobojno negativni, dok se u nekim emigrantskim časopisima i novinama te osobe čak demoniziralo. Za Jakova Blaževića Mikulić je kazao da je kalkulirao s konjunkturom hrvatstva. Smatralo se da je on jedan od rijetkih koji će ,izdati“ reformnu struju u vrhu hrvatske Partije, ako dođe do teške situacije, no to je ipak učinio. Mikulić je dodao kako ga je osobno poznavao i da je Blažević bio gost u njegovoj kući. Čini se da je Mikulić bio iskreno iznenađen Blaževićevim svrstavanjem na protureformatorsku stranu, s obzirom na to da njegovo pisanje ide u smjeru poruke kako Blaževićevo ,izdajstvo" nema granica. Juru Bilića i Marinka Gruića, daljnje pripadnike protureformatorske struje, oslikao je kao oportuniste, koji su se na sve načine pokušali približiti onima koje su kasnije , izdali““. Još jednog od njih, Josipa Vrhovca, slično je opisao, podcrtavajući kako je bio užasno ambiciozan. Potpuno je suprotan slučaj, prema njemu, generala Viktora Bubnja. Mikulić je tvrdio da Bubanj nije vrijedan suza koje neki u emigraciji rone za njim te da bi on bio zadnji hrvatski general kojega bi Srbi i unitaristi otrovali, kako se govorilo u emigraciji. Bubanj je, prema Mikuliću, boravio u Jaski na odmoru, a bio je i pozvan na razgovor s Tripalom i Dabčević-Kučar. Njima je rekao da on nema o čemu razgovarati s nacionalistima $\mathrm{i}$ šovinistima. ${ }^{40}$

Govoreći o Mikulićevim susretima i poznanstvima, opis triju susreta s Titom posebno je živopisan. Njegov je sukus bio kako je Tito najgori i okorjeli diktator. Prilikom jednog od tih triju razgovora našli su se na potpuno suprotnim stranama glede fenomena iseljavanja jer je Tito tvrdio da je problem općejugoslavenski, dok je Mikulić dokazivao kako se on najvećim dijelom odnosi na Hrvate. ${ }^{41}$ Treba kazati da spomenuti susreti nisu mogli biti potvrđeni, no isto tako treba reći kako je, s obzirom na Mikulićevu poziciju u sustavu vlasti, do susreta moglo doći. Ono što je manje vjerojatno jest to da je Mikulić direktno oponirao Titu na način na koji je to opisao.

\footnotetext{
39 Isto, 23. 2. 1982., 17.

$40 \quad$ Isto, 23. 3. 1982., 17.

${ }_{41} \quad$ Isto, 6. 4. 1982., 17; Isto, 30. 3. 1982., 17.
} 
Mikulić je, prema svojim riječima, nastojao na lokalnoj razini činiti ono što je reformno orijentirani hrvatski komunistički vrh pokušavao na nacionalnoj, dakle potvrđuje ocjene koje su dane na temelju opisa nekih njegovih poteza iz njegova dosjea. Tako je pripovijedao o naporima da poveća broj policajaca hrvatske nacionalnosti u svojoj općini i raznim preprekama s kojima se susreo na tome putu, što je još jedan vid njegove djelatnosti koji pronalazi potvrdu u materijalima iz dosjea. Slične napore ulagao je i u mijenjanje strukture općinskih dužnosnika. Mikulić je na neizravan način pokušavao prikazati Holjevca i kao inicijatora stvaranja neke vrste poluvojničkih postrojbi, koje bi bile spremne intervenirati baš u situaciji kakva je nastala nakon sloma Proljeća. Stoga je i Mikulić intenzivno radio na uvježbavanju vatrogasnih postrojbi jer je Holjevac kazao kako je od vatrogasca do vojnika samo jedan korak. Nadalje, Holjevac ga je očito inspirirao i svojim radom u Matici iseljenika pa je Jastrebarsko počelo razvijati kontakte s gradišćanskim Hrvatima. Opisao je svoje sudjelovanje na sastanku u Gradskom podrumu u Zagrebu kada se osnivao Hrvatski gospodarski glasnik, a tada se našao u društvu spomenutog Mate Novačića, Stipe Mesića i Tripala. Naravno, osnivanje ogranka Matice hrvatske nezaobilazna je tema, kao i negativne reakcije koje su uslijedile iz Vrginmosta, a navodno i iz Beograda. Ovi njegovi potezi pretvorili su ga, prema njemu, u sve češću metu Saveza boraca. Tome je posebno pridonosila njegova maksima kako je došlo vrijeme da se prestane ispitivati ,tko je bio u Bojni, a tko je bio u Brigadi“, dakle na strani NDH, odnosno u partizanima. Pomirenje i zajednički nastup Hrvata najprisutnija je misao u njegovim tekstovima pa je tako napisao i sljedeće: „Naši uspjesi su bili u zajedništvu, u iskrenoj želji za praštanje i izmirenje“. Sva su ova nastojanja i gibanja, prema Mikuliću, unijela „,u Hrvatsku radost i veselje, a ono što je važno i ostalo, trajno živi, i danas je činjenica da se je $\mathrm{u}$ to vrijeme vratilo ponos i dostojanstvo svim građanima Hrvatske“" ${ }^{42}$ Cijeli jedan nastavak Mikulić odvaja za prikaz ratnih događaja u svome selu, čiji je cilj dokazati kako su i na jednoj i na drugoj zaraćenoj strani postojali domoljubi i rodoljubi, koji su se unatoč greškama i zabludama u svojim djelima prvenstveno vodili ljubavlju prema domovini i Hrvatima. ${ }^{43}$

U ovome kontekstu posebno je važna Mikulićeva želja da afirmira hrvatsku komponentu jugoslavenskog partizanskog pokreta. ${ }^{44}$ To je bila i jedna od glavnih tendencija reformnoga pokreta, kako bi se pobila često ponavljana teza o genocidnosti hrvatskoga naroda i povezivanje bilo kakvog jačeg iskazivanja hrvatskih nacionalnih osjećaja s ustaštvom. To se odnosilo na neke tendencije, npr. u historiografiji koncem pedesetih i šezdesetih, kojima se, među ostalim, suprotstavljao

$42 \quad$ Isto, 26. 1. 1982., 17; 2. 2. 1982., 17; 9. 2. 1982., 17; 16. 2. 1982., 17.

43 Isto, 16. 3. 1982., 17.

$44 \quad$ Isto, 9. 2. 1982., 17. 
i Tuđman. Sadkovich piše o povjesničarima „koji su podupirali tumačenje novije povijesti što je Srbe prikazivalo temeljnim narodom južnoslavenske države i koji su je branili od hrvatskog naroda, koji je prikazivan kao antisrpski, antisemitski i sklon genocidu“, držeći da je studija Velimira Terzića, direktora Vojnoistorijskog instituta JNA i bivšeg pripadnika vojske Kraljevine Jugoslavije, „okrivljavala stvaranje NDH za propast Jugoslavije i tvrdila da su svi Hrvati, osim sićušne manjine, aktivno podupirali ustaše i njihovu državu“. Tuđman je, pak, uzroke brzog sloma Jugoslavije tražio u korumpiranosti i represivnosti režima, na čijemu su čelu stajale srpske elite, kao što je ,preispitivao tvrdnju da su Srbi dominirali u narodnooslobodilačkom pokretu u Hrvatskoj, koji je on obilježio kao autohton hrvatski pokret uza znatnu srpsku komponentu“. „U slučaju Hrvatske vjerovao je kako je vrijeme da se priznaju doprinosi koje su Hrvati dali u narodnooslobodilačkoj borbi i stvaranju socijalističke Jugoslavije umjesto da se zadržava na njihovoj ulozi u NDH“, bilježi o Tuđmanovim nastojanjima Sadkovich. ${ }^{45}$

Mikulić je o nekima od gornjih pitanja zaključio: „Meni je danas, više negoli ikada prije, jasno da je Hrvatsku u prošlome ratu spasila samo naša podvojenost, jer katastrofa bi bila potpuna, da se na pobjedničkoj strani nije našao velik broj Hrvata, i to na zavidno visokim položajima“. Da su svi Hrvati branili NDH, danas se u Hrvatskoj za hrvatsko ime više ne bi znalo, tvrdio je Mikulić. Uz ovakve poruke, ponovno i usporedno zagovarao je oprost i zaboravljanje „tko je bio na kojoj strani“". Spomenuo je tako Zvonimira Komaricu, kojemu se također sudilo nakon sloma reformnog pokreta, a koji je, prema Mikuliću, zapravo prvi organizirao partizanski odred u okolici Zagreba, prije onoga u Sisku. Naveo je i da je bio ranjen, zatočen u Lepoglavi, a kasnije komesar brigade. Istaknuo je i najpoznatiju činjenicu o Komarici: da je bio jedan od trojice preživjelih iz ustaškog logora Kerestinec. Ponovno spominjući još neke smijenjene oficire hrvatske nacionalnosti, istaknuo je i slučaj Zvonimira Červenka, koji je izdržao 18-mjesečnu zatvorsku kaznu. Srpski stražari u zatvoru Gradiška nazivali su ga ustašom, zbog čega je bio strašno deprimiran jer je postao partizan sa 16 godina. Mikulić je i ovom prilikom progovorio o negativnom i neprijateljskom odnosu znatnog dijela emigracije prema onima koji su bili u partizanima, ali dodavši kako su oni u Hrvatskoj početkom sedamdesetih godina imali potpuno drukčiji odnos prema osobama koje su vršile neke funkcije u NDH, tvrdeći kako im je najvažnije bilo „tko je za Hrvatsku, a tko je protiv nje“ ${ }^{46}$ Posljednja dva nastavka posvetio je svome uhićenju i suđenju, posebno dokazujući neozbiljnost i netočnost optužbi na vlastiti račun. Jedna od njegovih završnih poruka bila je kako je iskustvom Hrvatskog proljeća u kratko vrijeme Hrvatskoj vraćena vjera u sebe, odbijajući kritiku nekih emigranata da se samo htjelo „malo više deviza“. Sma-

45 SADKOVICH 2010: 107-108, 113, 214.

46 Sjećanja na Hrvatsko proljeće, Hrvatski tjednik, 9. 3. 1982., 17. 
tralo se, napisao je Mikulić, da „nema više te snage koja može slomiti ogromnu volju Hrvata za slobodom i samostalnošću“. ${ }^{47}$

Razmatrajući uvodne retke u Mikulićevim sjećanjima, za dio toga teksta može se zaključiti kako je Mikulić portretirao niz hrvatskih političara - komunista na civilnim dužnostima i vojnih oficira, koje je prikazao kao nacionalno svjesne Hrvate. Oni su, prema njemu, teškim, upornim i polaganim radom nastojali mijenjati krute strukture, s ciljem jačanja i poboljšanja položaja Hrvatske $\mathrm{u}$ Jugoslaviji te hrvatskog naroda u svojoj republici. Jedna od tema koju su politički emigranti otvarali bila je ta je li konačan cilj reformnog pokreta bila samostalna, pa u nekim varijantama i komunistička hrvatska država. Odgovor je najčešće bio niječan, pogotovo kada je u pitanju bio reformno orijentirani vrh hrvatske Partije. I tu im Dabčević-Kučar u svojim memoarima daje za pravo, pišući: „Smatrali smo mogućom demokratsku slobodnu državu Hrvatsku u Jugoslaviji i socijalizmu“". ${ }^{8}$ Nešto povoljnije ocjene bile su o Matici hrvatskoj i pogotovo studentskom pokretu, ali je i tu bilo prisutno dosta sumnji, pogotovo od strane nekih radikalno antikomunistički raspoloženih emigranata. Mikulić je naizgled ostao po strani te rasprave, ne želeći u ovim tekstovima izravno ulaziti u nju. No, subtekstualna poruka itekako postoji i ona kaže kako su od vrha hrvatske Partije pa do njenih najnižih položaja postojali ljudi koji su držali da je projekt Jugoslavije baziran na krilatici „bratstvo i jedinstvo“ propao i da su u iznimno teškoj situaciji pokušali učiniti što više kako bi se popravio položaj Hrvatske i Hrvata. Isto tako, konačna postaja takvih nastojanja trebala je biti hrvatska samostalnost. Štoviše, Mikulić u nekim primjerima kao da želi poručiti da je bilo hrvatskih komunista koji su i pred Drugi svjetski rat i tijekom njega priželjkivali samostalnu hrvatsku državu, ali su silom prilika, kao manje zlo, prihvatili jugoslavenski okvir. ${ }^{49}$ Unatoč tome što je Mikulić na slobodi u inozemstvu djelovao iznimno pomirljivo prema emigrantima nekada povezanima uz NDH i drugim antikomunistima, u svojim je sjećanjima jasno izrekao što bi za njega bilo „veće zlo“ - nesudjelovanje dijela Hrvata u partizanskom pokretu vodilo bi u konačnici prema nestanku hrvatskog naroda. Nakon sloma reformnog pokreta neki su emigranti, ocjenjujući njegove dosege, držali kako njegovi protagonisti zapravo nisu mnogo postigli, niti su mnogo tražili, pa otuda i Mikulićeva referenca na to da su navodno željeli dobiti samo „malo više deviza“. Mikulić je, pak, želio poručiti, pišući kako je Proljećem Hrvatska vratila vjeru u sebe, odnosno da je hrvatski reformni pokret - ne, naravno, u

47 Isto, 20. 4. 1982., 17; 27. 4. 1982., 17.

48 DABČEVIĆ-KUČAR 1997: 122.

49 Slično je nastupio i Bruno Bušić u svojoj raspravi Hrvatski ustaše i komunisti, nastojeći približiti, pa čak u nekim aspektima i izjednačiti ciljeve hrvatskih komunista i članova Ustaškog pokreta u tridesetim godinama te na početku Drugog svjetskog rata. 
potpuno otvorenoj formi - trideset godina nakon sloma kraljevinske Jugoslavije pokazao da hrvatski narod nije zadovoljan njenom komunističkom varijantom i da želi samostalnu i neovisnu državu. Unutar reformnog pokreta postojala su razna strujanja, ali jedna od dominantnijih, uz nacionalnu komponentu, bila je ona liberalno-demokratska. To je značilo da se ideja hrvatske državnosti, od njenih pobornika i protivnika, u Jugoslaviji i inozemstvu, više ne mora i/ili ne može isključivo vezati, naslanjati na iskustvo Nezavisne Države Hrvatske. To je, na temelju Mikulićeva teksta, unatoč propasti reformnog pokreta, bila velika pobjeda hrvatske državotvorne ideje.

Većeslav Holjevac neopravdano je zaboravljena ili premalo isticana figura $u$ radovima o hrvatskom reformnom pokretu. Jedan od razloga za takav trend zasigurno je činjenica kako je preminuo sredinom 1970. godine pa nije sudjelovao u posljednjoj, kasnije i danas javnosti najupečatljivijoj fazi pokreta. Međutim, ako se u obzir uzme njegov ratni put, popularnost u široj javnosti, poslijeratna karijera, kako u vojsci tako i na civilnim dužnostima, valja konstatirati da je Holjevac u drugoj polovini šezdesetih bio hrvatski intelektualac, koji se u stanovitoj mjeri našao u raskoraku s nekim od službenih stavova režima, a koji je imao najimpresivniji životopis; otpadnik od režima u kojemu je imao najviši stupanj moći i odgovornosti u odnosu na ostale disidente i nepoćudne. Mikulićevi reci o Holjevcu definitivno sadrže divljenje i poštovanje, no generalna slika koju o Holjevcu iznosi Mikulić ipak predstavlja realan prikaz, uz to što donosi neke nepoznate ili slabije poznate podatke o njemu. Kako se Mikulić nije libio surađivati s osobama koje su bile okarakterizirane i suđene kao hrvatski nacionalisti, čini se da ni Holjevac u nekim slučajevima nije imao takvih zadrški. U arhivi Vinka Nikolića, člana Ustaškog pokreta, književnika i političkog emigranta, nalazi se razglednica koju mu je Holjevac poslao, u kojoj mu želi sve najbolje u 1970. godini i zahvaljuje što mu je poslao stanovitu knjigu. ${ }^{50}$

Govoreći o visokim vojnim oficirima o kojima je Mikulić pisao, Dabčević-Kučar također se referirala na Rukavinu kao sjajnog čovjeka, ali i njezina prijatelja. Istaknula je važnost teritorijalne obrane jer bi se tako, osim JNA, koja je bila pod dominacijom Srba, oružje našlo i u rukama ,naših, hrvatski i demokratski orijentiranih ljudi“. I ona je pisala o nacionalnoj podzastupljenosti Hrvata u visokom oficirskom kadru, dodajući kako je cilj reformne struje u SKH bio i na tome polju uvesti promjene. Tako je Titu predložila Bobetka za zapovjednika Pete vojne oblasti, no on ju je oštro upozorio da se ne miješa u takva pitanja. Naime, Armija je bila jedno od područja na koje je Tito gledao kao na svoje osobno leno, ne dopuštajući ikome da zadire u njega. ${ }^{51}$

50 KRAŠIĆ 2016: 216.

51 DABČEVIĆ-KUČAR 1997: 420, 426, 428-432. O tome vidi i: I. GOLDSTEIN I S. GOLDSTEIN 2015: 571-575. 
Što se, pak, Bobetka tiče, iz njegovih je memoara vidljivo zašto se slagao s Mikulićem u nizu pitanja. Dok je potonji bio dijete u vrijeme rata, Bobetko je u njemu sudjelovao i dočekao njegov kraj u činu pukovnika. No, baš kako je Mikulić izgubio oca u partizanima, Bobetkov je kao partizan strijeljan od strane četnika, dok mu je još četvero braće stradalo na toj strani u ratu. Mikulić je spomenuo potez Bobetkove majke nakon sloma Proljeća, a Bobetko je za nju napisao da se potpuno razočarala kada je „donijet drastičan zakon za hrvatske ljude“. Poput Mikulića, istaknuo je da je hrvatski narod imao sreću što se našao na strani pobjednika u ratu jer bi u suprotnome bilo još Bleiburga, a do Domovinskog rata ne bi ni došlo. U duhu hrvatske pomirbe tvrdio je kako su svi hrvatski sinovi željeli hrvatsku državu. Slično kao i Mikulić, koji je pisao o državotvornim pogledima hrvatskih komunista, istaknuo je da su se u Narodnooslobodilačkom pokretu i ZAVNOH-u nalazili brojni Hrvati, koji su, prema njemu, bili naivni i nisu znali iskoristiti potencijal koji im se nudio za postizanje što boljeg položaja Hrvata, pa makar i unutar Jugoslavije. Ne treba posebno isticati kako je i on naveo primjere zapostavljanja Hrvata u napredovanju u vojnim karijerama. Bobetko je odao priznanje reformnom dijelu hrvatskog rukovodstva, koje je pokrenulo demokratizacijske procese, držeći da nema boljitka bez radikalnih političkih, društvenih i gospodarskih reformi. I na koncu, upravo poput Mikulića, podcrtao je da su Hrvati 1971. godine mnogo dobili jer su, među ostalim, „Republika Hrvatska i hrvatski narod već 1971. godine bili na putu uspostave svoga suvereniteta“. Bobetko je uz ovu izjavu na neki način poručio da 1971. godina i hrvatski reformi pokret stoje u temelju hrvatskog osamostaljenja dvadesetak godina kasnije. ${ }^{52}$ I iz Mikulićevih tekstova može se zaključiti kako je i on iskustvo hrvatskog reformnog pokreta ocijenio nečime na čemu bi valjalo graditi daljnji put prema hrvatskoj državnoj samostalnosti.

Kazano je da je vrijednost Mikulićevih tekstova i u tome da neke osobe nije prikazao isključivo u svijetlim ili tamnim tonovima, što posebno vrijedi za Blaževića, Kufrin-Bulat i njezina supruga Radu, koje su mnogi u zemlji, a pogotovo u emigraciji, doživljavali kao oštre protivnike reformnog pokreta, beogradske sluge i izdajnike. Jedan je emigrantski list čak pozivao na ubojstvo Bakarića i Blaževića nakon sloma reformnog pokreta. ${ }^{53} \mathrm{I} u$ radu spominjani Josip Šentija u svojoj analizi reformnog pokreta napisao je da su fronte bile izmiješane, misleći na to kako se u nizu slučajeva hrvatske komuniste, pogotovo one iz samoga vrha vlasti, nije u svim trenucima moglo jasno definirati kao pristaše, odnosno protivnike reformnog pokreta. ${ }^{54}$ Može se navesti još jedan primjer, najmoćnije osobe u Hrvatskoj, Vladimira Bakarića, jer su neke postavke njegove politike u šezde-

52 BOBETKO 1996: 7-10, 15, 20, 69-70.

53 Hrvatska borba, veljača 1972., 17.

54 JAKOVINA 2012: 10. 
setima, pa i pedesetima išle za time da se smanje ovlasti federacije i uz Edvarda Kardelja bio je prepoznat kao protagonist reformističke struje u spomenutome periodu. ${ }^{55}$ Radu Bulata povezivalo se s prijedlogom za stvaranje srpske autonomne jedinice u Hrvatskoj u jeku reformnog pokreta, tako da su Mikulićeve informacije o njemu i mišljenje kako je otišao na taj put izrazito zanimljive, ali i indikativne. Unatoč tome što je očito dolazio u sukobe s pripadnicima srpske nacionalnosti, u tekstu zapravo dolazi na iste pozicije kao i Dabčević-Kučar kada su u pitanju Srbi u Hrvatskoj - privući ih ideji snažnije, bogatije Hrvatske, što će biti na korist svim njenim stanovnicima te razviti osjećaj povjerenja između dvaju naroda na principu ravnopravnosti.

Opis Josipa Broza Tita jest dio u kojem se ogleda Mikulićeva neobjektivnost. Dva obilježja Titove politike bila su izmjenjivanje razdoblja „stezanja“ i „popuštanja“ političke kontrole i pritiska na društvo, a drugo laviranje između reformističke struje, koja se, generalno govoreći, zalagala za federaciju u stvarnosti, a ne samo „na papiru“, za gospodarske modele bliže onima na Zapadu te one centralističke, pri čemu je uzor bio Sovjetski Savez, snažna središnja država s čvrstom kontrolom i u ekonomiji. Bez Titove podrške reformističkoj struji, koja je posebno došla do izražaja smjenjivanjem predvodnika centralističke struje i tada drugog čovjeka u Jugoslaviji, Aleksandra Rankovića, sa svih njegovih dužnosti, nastanak reformnog pokreta u Hrvatskoj ne bi bio moguć. Jedna teorija, s mnogo argumenata, kaže: kada je Tito skršio otpore određenim reformama - pogotovo kada su izglasani ustavni amandmani sredinom 1971. godine - reformni pokret u Hrvatskoj nije mu bio više potreban, dapače, smetao mu je i iritirao ga te mu je stoga odlučio stati na kraj. Vezano za prethodnu rečenicu, a u kontekstu, primjerice, Bušićevih ocjena o reformnom dijelu hrvatskog rukovodstva, bez njegove odluke da djeluje prema političkim protivnicima uglavnom bez primjene represivnih mjera, ne bi bio moguć razvoj i djelovanje elemenata reformnog pokreta na način na koji se to zbivalo. ${ }^{56}$

Ideju o hrvatskom miru ili pomirenju, zvanu upravo tako ili nekako drugačije, $\mathrm{u}$ javnosti su prezentirale neke struje u hrvatskoj političkoj emigraciji - s jedne strane, krug oko spomenutog časopisa Nova Hrvatska, koji su osnovali mladi emigranti na čelu s Jakšom Kušanom, nepovezani s događajima iz Drugog svjetskog rata, a s druge organizacija Hrvatski narodni otpor i zloglasni Vjekoslav Luburić, zvan Maks, čovjek zadužen za logorski sistem NDH, ustaški general i ratni zločinac. Objema varijanta bilo je zajedničko to što su predlagale različite moduse kako prevladati ideološko-političke rovove i ponore između Hrvata, stvorene prvenstveno za vrijeme ratnih događaja, a s ciljem stvaranja samostalne i demokratske hrvatske države. Međutim, među njima su postojale krucijalne razlike,

55 MUJADŽEVIĆ 2011: 215-227.

56 RADELIĆ 2008: 330-331, 333-335, 352-356, 462. 
koje su dijelom proizlazile i iz dotadašnjih životnih puteva i ideološko-političkih opredjeljenja njihovih tvoraca. Dočim je mladi Kušan mogao u svojim analizama polaziti od trenutnog političkog stanja u Jugoslaviji s kraja pedesetih i početka šezdesetih, Luburić je svoje morao započinjati tumačenjima procesa i događaja iz rata jer je u njima sudjelovao. Kušan je u fokus stavljao mlade nekomunističke generacije, u to uključujući i neke starije, demokratski opredijeljene pojedince i grupe (recimo, iz Hrvatske seljačke stranke) te dio hrvatskih komunista za koje je držao da su se našli na svojevrsnom brisanom prostoru, rastrgani između mogućnosti potpunog pokoravanja Beogradu i snažnijeg zauzimanja za prava hrvatske federalne jedinice. To su bili akteri koji su, za boljitak hrvatskog naroda, trebali naći zajednički jezik. Luburić je želio objasniti postupke ustaša, tj. svih vezanih uz NDH te barem dijela hrvatskih partizana na način koji mu je odgovarao da te dvije skupine približi dvadesetak godina od vremena kada su se gledali preko nišana i bili ljuti protivnici (što su ostali i nakon rata). Njegova sljedeća poruka, puna subjektivizma i tendencioznosti, najbolje sažima to nastojanje: „I Ustaše i istarsko-dalmatinski partizani su se borili za slobodu Hrvatske Države, da bi na koncu jedni propali poviestnim okolnostima, koje su im bile nesklone, a drugi bili izigrani i prevareni. Istarski i Dalmatinski partizani su danas sviestni da su počinili pogrešku, boreći se protiv Ustaša i Domobrana, isto što se i Ustaše kaju što su nepobieđeni napustili Hrvatsku i predali se“. ${ }^{57}$ Dakle, dio hrvatskih partizana i ustaše imali su zapravo isti cilj, no niz silnica ih je na tome putu da ga, možda i zajedničkim djelovanjem ostvare, spriječio. Stoga je valjalo prijeći preko starih sukoba i ponovno zajedničkim snagama raditi na ostvarenju hrvatske samostalnosti.

Tuđman je, baš kao i Luburić, bio dio toga sukoba i opširno je o njemu pisao u svojim historiografskim i drugim djelima. Ostaje pitanje u kojem je trenutku to počeo činiti svjesno i s određenim ciljem (borba za drukčije rješenje položaja Hrvatske unutar Jugoslavije, a onda hrvatska samostalnost), no njegovo pisanje o uzrocima nastanka Ustaškog pokreta kao reakcije na postupanje dijela srbijanskih elita u Kraljevini Jugoslaviji razdvajalo je fenomen ustaštva i NDH od klasičnog tumačenja da se radilo o običnoj marionetskoj tvorevini Osovine te da su ustaše bili najobičniji zločinci. Takva interpretacija ovih pitanja mogla se iskoristiti za promišljanja unutar ideje o hrvatskom miru. Na jednome polu dio bivših ustaša i osoba vezanih uz NDH priznavao je dijelu hrvatskih partizana da je njihova borba u sklopu Narodnooslobodilačkog pokreta protiv, u prvome redu, Talijana, bila opravdana, a neki hrvatski komunisti priznavali su kako je u korijenima ustaštva ležala i opravdana želja za stvaranjem samostalne hrvatske države, temeljena na shvaćanju kako Hrvati nemaju budućnost u Jugoslaviji, a poduprta brojnim agrumentima (od atentata na pripadnike HSS-a u beogradskoj Skupštini nada-

57 KRAŠIĆ 2016: 38. 
lje). Takva su razmišljanja bila moguća u stanju u kojem se antikomunistički dio hrvatskih političkih snaga uglavnom prestao nadati da će vanjskim djelovanjem (Treći svjetski rat) doći do rušenja komunizma i Jugoslavije te da bi unutarnji razvoj događaja, u kojem je i dio hrvatskih komunista mogao sudjelovati, mogao presuditi spomenutima i dijelu hrvatskih komunista koji su sve manje vjerovali u mogućnost daljnjeg razvitka i napredovanja hrvatskog naroda unutar Jugoslavije, barem u obliku u kakvom je tada, šezdesetih i početkom sedamdesetih, postojala.

Iako je Mikulić, kako je rečeno, bio dijete u vrijeme rata, odlučio je zauzeti stav i o nekim pitanjima iz toga vremena. Stoga je neke njegove navode moguće usporediti s onima Luburićevim i Tuđmanovim jer je, baš kao i Luburić, primjerice, nastojao približiti hrvatske partizane i one koji su bili na strani NDH, pišući kako su se na objema zaraćenim stranama nalazili pojedinci kojima je na prvome mjestu u njihovu djelovanju bio njihov narod i domovina, a ne ideologija! U časopisu Drina, koji je izdavao Luburićev HNO, u tome je duhu stajala i ova konstatacija: „Ako se u tom strašnom sukobu (sukobu NOP-a s NDH, op. a.), ekscesivnim načinom borbe ogriješio i koji Hrvat, svatko znade, da takve pogreške nisu potekle iz zločinačkih pobuda, već su ona posljedica bezgranične ljubavi, prema hrvatskoj zemlji, koju je hrvatski vojnik branio od tuđina“" ${ }^{58}$ Slično kao i Luburić, Mikulić je na neizravan način poručivao kako su se u NOP-u nalazili Hrvati koji su priželjkivali samostalnu hrvatsku državu, ali su u danim okolnostima izabrali poduprijeti jugoslavenski državni okvir, kao „manje zlo“. Iako to nije otvoreno kazao, iz njegovih riječi proizlazi da je hrvatski partizanski pokret ipak više učinio na očuvanju hrvatskog naroda i njegova ugleda u svijetu negoli ustaški. To je značilo da bi se svehrvatska pomirba trebala izvesti dijelom na tim temeljima. U tome kontekstu treba ponovno spomenuti Tuđmana, koji je svoja razmišljanja i program bazirao na pravaškoj ideji hrvatskog suvereniteta Ante Starčevića, zatim na republikanskom seljačkom pokretu braće Radić te, na koncu, na iskustvima hrvatskog radničkog pokreta i hrvatske komponente antifašističkog pokreta u Jugoslaviji. ${ }^{59}$ Ideja o hrvatskom pomirenju među hrvatskim političkim emigrantima s vremenom je sve više dobivala na snazi, a Tuđmanov primjer, kao i nekih drugih intelektualaca, pokazao je kako je pristalica nekih njenih varijanti, koje su bile brojne, bilo i među Hrvatima u Jugoslaviji. S obzirom na ograničenost sloboda izražavanja u Jugoslaviji, danas su poznati takvi koncepti koji su se publicirali u inozemstvu među političkim emigrantima. Velik je broj takvih tekstova, kao što su, uostalom, bili i Luburićevi, kao podlogu za hrvatsku pomirbu ipak uzimao iskustvo NDH; 10. travnja označavao se kao navodni plebiscit hrvatskog naroda za samostalnost, dok se u stranu guralo i nije spominjalo stvari poput masovnih zločina, fašističkog karaktera NDH i slično. Bivše hrvatske partizane i komuniste u pomirbi iz toga kuta gledanja vidjelo

Isto: 36 .

59 SADKOVICH 2010: 214. 
se kao osobe koje u nadolazećoj borbi za hrvatsku državnu samostalnost u prvim redovima moraju okajati svoj teški „grijeh“ svrstavanja na „krivu stranu“ u ratu i nakon njega. Mikulićev nastup u tim pitanjima, kako je pokazao dosadašnji tekst, bio je prilično drukčiji. Stoga je neobično važno istaknuti njegove poglede na tu problematiku, kao čovjeka koji je bio svojevrsno strano tijelo među hrvatskim političkim emigrantima, kao i uočiti sličnost njegovih pogleda s onim Tuđmanovima.

Promatranje načina na koji su hrvatsku pomirbu zamišljali Luburić i osobe na neki način vezane uz NDH, zatim one koje su bile dio partizanskog pokreta i kasnije članovi Partije, poput Tuđmana, Mikulića ili, pak, Bobetka, do onih političkih emigranata koji nisu bili vezani ni uz jednu stranu u ratu (od starijih kao što je bio Bogdan Radica do mlađih Mate Meštrovića, zatim Kušana i nekih drugih ljudi vezanih uz Novu Hrvatsku, poput Tihomila Rađe ili Gojka Borića) dovodi do zaključka kako su početne pozicije stvaraoca pojedinih varijanti te ideje imale presudnu ulogu na njihove oblike. Ideju o hrvatskom miru često se se promatra kao pokušaj (ostvareni ili ne) pomirenja dviju totalitarnih ideologija - fašizma i komunizma, odnosno u hrvatskom slučaju ustaša i partizana (i članova Partije). Međutim, tu se prvenstveno radilo o pomirenju osoba, a ne ideologija; pomirenju nekad zaraćenih osoba te suradnji njihovih potomaka na stvaranju samostalne hrvatske države. Ono je bilo moguće izvesti, a u tome su se slagali svi, samo na demokratskoj osnovi. Buduća hrvatska država mogla je opstati jedno kao parlamentarna demokracija. No, istodobno nije bilo svejedno hoće li se projekt pomirbe voditi prema receptu nekoga tko je bio vezan uz NDH (izravno ili drugačije, kroz članove obitelji, nekritički pristup tome fenomenu i slično), nekoga tko je bio pripadnik partizanskog pokreta i član Partije (kao što je bio Tuđman) ili, pak, nekoga tko tijekom svojega života nije imao dodira s totalitarnim ideologijama i režimima. Sukladno s time, ostvarenje suradnje najvećeg broja Hrvata u stvaranju samostalne i demokratske hrvatske države onako kako je to izvedeno pod vodstvom Tuđmana i Hrvatske demokratske zajednice nije predstavljalo jedini način za ostvarenje tog cilja. Mikulićevi su tekstovi u tome kontekstu bitni zato što su u javnost dospjela neka njegova razmišljanja o tome problemu, u trenucima kada se glas Hrvata, koji su u barem jednom dijelu svojega života bili dio lijevog političkog spektra, nije mogao čuti u svojoj punini i bez cenzure.

\section{Zaključak}

U završnom osvrtu na rad, na početku svakako treba istaknuti kako je predstavljanjem Mikulićeve djelatnosti, u prvome redu političke, s konca šezdesetih i početka sedamdesetih, potvrđeno da je itekako imao osnove za davanje ocjena o nizu osoba, događaja i procesa kojih se dotaknuo u svojim memoarskim zapisima. Jedno od velikog broja pitanja koja se vežu uz narav hrvatskog reformnog pokreta jest $i$ to jesu li tri centralna elementa unutar njega - reformni dio hrvatske 
Partije, Matica hrvatska i studentski pokret, u nekoj mjeri surađivali. Već je istaknuto kako su im strategijski ciljevi bili različiti, da su upotrebljavali i različite taktičke poteze i da su zastupali različite stupnjeve dinamike promjena koje su priželjkivali. Međutim, među tim su grupacijama itekako postojali kontakti i u nekim pitanjima pokušaji suradnje. Franjo Mikulić bio je jedna od osoba koje su predstavljale takav primjer. Bio je član Partije i dio sustava vlasti, prijateljevao je i surađivao s Bobetkom, Mutkom, Pirkerom, pa čak i Tripalom, dakle ne samo s običnim članovima Partije nego ujedno i istaknutim nositeljima vlasti u civilnoj i vojnoj sferi. S druge strane, bio je predsjednik Ogranka Matice hrvatske u Jastrebarskom pa se susretao i surađivao s Veselicom, Đodanom (koji će ljeti 1971. godine biti izbačeni iz Saveza komunista), Tuđmanom ili Gotovcem. Na neki je način izlazio iz kruga tadašnjeg primjerenog ponašanja za dužnosnika SK pa je surađivao i s bivšim osuđenim hrvatskim „nacionalistima“. Mikulićevi tekstovi imaju pregršt podataka za koje se potvrda može pronaći u dokumentima koji se nalaze u njegovu dosjeu.

I ne radi se tu samo o osobama, s obzirom na to da je na njima u prethodnome odlomku stavljen naglasak. Mikulić nije sudjelovao tek u trivijalnim razgovorima i druženjima, već u nekima od događaja i procesa koji su obilježili reformni pokret. U svojim je tekstovima opisivao nacionalnu podzastupljenost Hrvata u nekim državnim službama, a dosje otkriva kako je i sâm nastojao na području Općine Jastrebarsko vršiti kadrovske promjene po uzoru na reformni dio hrvatskog rukovodstva, koji je to činio na republičkoj razini, ali i izvan tih uzora. Nadalje, sudjelovao je u razgovorima o gospodarskim pitanjima, kao npr. o osnivanju Hrvatske gospodarske banke. Nastanak reformne i centralističke struje unutar SKJ imao je svoj temelj ili barem jedan od temelja upravo na ekonomskom polju. Isto tako, različite ekonomske teme bile su među najprisutnijima u javnosti za postojanja reformnog pokreta. I studentski je štrajk u studenome 1971. godine započeo s parolama o potrebi što skorijeg mijenjanja bankarskog, vanjskotrgovinskog i deviznog sustava. Jedan od procesa koji je obilježio Hrvatsko proljeće bilo je širenje ogranaka Matice hrvatske i brz porast njezina članstva. I Mikulić je bio dio toga procesa jer je postao predsjednik Ogranka i organizirao razne manifestacije. Reformnim pokretom promijenilo se tretiranje iznošenja elemenata hrvatskog nacionalnog identiteta pa su u to vrijeme neki njegovi iskazi (korištenje nacionalnom zastavom, grbom, pjevanje nekih pjesama i slično) postali prihvatljivi, dok ih se u ranijem razdoblju tretiralo kao oblike nacionalizma, odnosno ustaštva i fašizma. Mikulić je također objeručke prihvatio novostvoren prostor za takvu vrstu izražavanja. I ne samo to - u nekim se svojim istupima velikim koracima odmicao od komunizma i Jugoslavije u smjeru demokracije i samostalne hrvatske države. Tužitelji su nakon sloma reformnog pokreta muku mučili s dokazivanjem optužbi na račun, primjerice, članova iz vrha Matice hrvatske ili studentskog vodstva za nacionalizam. Njihove su se javne izjave mogle svesti u socijalističke 
i jugoslavenske okvire. Mikulić ih je, pak, u svojim javnim nastupima itekako prelazio. Zbog te karakteristike, člana Partije i dijela režima koji istupa protiv te Partije i protiv toga režima, Mikulićevi memoari zaslužuju pozornost. Niz hrvatskih komunista razočarao se Jugoslavijom nakon sloma reformnog pokreta, ocjenjujući kako je daljnji razvoj Hrvatske u Jugoslaviji nemoguć, i prešao na pozicije potrebe stvaranja samostalne hrvatske države. Mikulić je takvo gledište imao i prije sloma pokreta. Još jedan od procesa o kojem se u ovome periodu naveliko raspravljalo bili su snažni emigracijski valovi koji su zahvatili Hrvatsku, a Mikulić je i u takvim razgovorima bio prisutan.

Ne smije se propustiti istaknuti važnost Mikulićeve interpretacije hrvatskog partizanskog pokreta, kako u kontekstu tendencija u Hrvatskoj i Jugoslaviji, od kojih su neke, vrlo snažne, išle za njegovim umanjivanjem, tako i u kontekstu tekstova koji su se o tome fenomenu mogli pročitati u emigrantskim tiskovinama. Također, Mikulić je, ne secirajući reformni pokret i propitujući konačne ciljeve njegovih pojedinih sastavnica, tome pokretu pripisao hrvatsku državotvornu dimenziju. Zagovaratelji hrvatske državne samostalnosti više se nisu morali pozivati samo na, prema Mikuliću, 10. travnja i stvaranje Nezavisne Države Hrvatske, s obzirom na to da su taj čin mnogi, među kojima je bilo i onih koji se nisu slagali s nizom praksi ustaškog režima, dapače, i teških kritičara, percipirali kao plebiscit Hrvata za samostalnu državu, bez obzira na sve ono što je kasnije uslijedilo. Sada se u inzistiranju na stvaranje samostalne hrvatske države, poručivao je Mikulić, moglo pozvati na Hrvatsko proljeće, nacionalno-demokratski pokret koji nije nosio nikakve negativne biljege i hipoteke. Mikulić je tvrdio kako je taj pokret rezultirao pomirbom velikog broja Hrvata, koji su se tijekom Drugog svjetskog rata i kasnije nalazili na suprotnim frontama. Njegovo pisanje u tome smjeru, a u kontekstu Tuđmana i Luburića, pokazuje do kojih su dodirnih točaka mogli doći pripadnici sukobljenih strana unutar hrvatskog nacionalnog korpusa iz vremena Drugog svjetskog rata i kasnije, smanjujući razmak koji je na jednoj strani održavala službena politika Partije, a na drugoj svi oni koji su inzistirali na svojevrsnoj sakrosanktnosti NDH i partizanski pokret u Hrvatskoj doživljavali najvećim dijelom srpskim, u kojemu je sudjelovala šaka „hrvatskih izdajica“.

Jedno od temeljnih obilježja hrvatskog reformnog pokreta bila je njegova pluralnost $\mathrm{i}$ heterogenost. I na iznimno malenome uzorku od triju osoba, tj. trojice sudionika pokreta koji su o njemu pisali u političkome izbjeglištvu - Mikulića, Markusa i Bušića - vidljiva je ta karakteristika. Na kraju, potrebno je ponoviti kako je ovaj izvor za proučavanje hrvatskog reformnog pokreta izniman s obzirom na vrijeme kada se pojavio, ali i mjesto izlaženja jer je bio najsustavniji osvrt na taj fenomen koji je producirala hrvatska politička emigracija. Isto tako, Mikulićevi su opisi u priličnoj mjeri lišeni želje da svoja sjećanja oblikuje u skladu s mogućim političkim ciljevima koje je imao u trenutku pisanja tekstova. 


\section{Bibliografija}

\section{Arhivski izvori}

Hrvatski državni arhiv. Fond 1561. Republički sekretarijat za unutarnje poslove Socijalističke Republike Hrvatske. Služba državne sigurnosti. Dosje 248 494. Franjo Mikulić.

\section{Periodika}

Bruno Bušić govori za HT Danicu. Hrvatski tjednik Danica, 6. 6. 1977., 8.

Bruno Bušić govori za HT Danicu. Hrvatski tjednik Danica, 13. 6. 1977., 8-9.

Bruno Bušić odgovara na pitanja Hrvatske borbe. Hrvatska borba, prosinac 1975., 6-7.

BUŠIĆ, Bruno. 1977. Hrvatska danas - i Rusija. Hrvatski tjednik Danica, 11. 7. 1977., $1,8-9$.

CRLJEN, Danijel, Franjo MIKULIĆ. 1979. Predizborna poruka članovima Hrvatskog narodnog vijeća. Hrvatski list, kolovoz 1979., 11.

Hrvatska borba, veljača 1972.

MARKUS, Zlatko. 1982. Vrijeme za Miku Tripala. Hrvatski list, 1. 5. 1982., 3, 10.

MIKULIĆ, Franjo. 1978. Tko to Hrvatskom proljeću priprema novo Karađorđevo. Hrvatski tjednik Danica, 25. 8. 1978., 8.

MIKULIĆ, Franjo. 1981. Sjećanja na Hrvatsko proljeće. Hrvatski tjednik, 1. 12. 1981., 17-18; 8. 12. 1981., 15; 18. 12. 1981., 13-14.

MIKULIĆ, Franjo. 1982. Sjećanja na Hrvatsko proljeće. Hrvatski tjednik, 26. 1. 1982., 17; 2. 2. 1982., 17; 9. 2. 1982., 17; 16. 2. 1982., 17; 23. 2. 1982., 17; 2. 3. 1982., 16; 9. 3. 1982., 17; 16. 3. 1982., 17; 23. 3. 1982., 17; 30. 3. 1982., 17; 6. 4. 1982., 17; 20. 4. 1982., 17; 27. 4. 1982., 17.

Quo vadis?. Hrvatska Država, svibanj - lipanj 1970., 3.

\section{Literatura}

BATOVIĆ, Ante. 2010. Liberalno-nacionalni pokret u Hrvatskoj od 1966. do 1972. $i$ svijet. Doktorska disertacija, Sveučilište u Zadru.

BILIĆ, Jure. 1990. '71, koja je to godina?. Zagreb: Centar za informacije i publicitet.

BOBETKO, Janko. 1996. Sve moje bitke. Zagreb: Vlastita naklada.

DABČEVIĆ-KUČAR, Savka. 1990. '71: hrvatski snovi i stvarnost. Zagreb: Interpublic.

GOLDSTEIN, Ivo. 1985. Podruštvljavanje obrambenog sistema u Jugoslaviji 1945-1983. godine. Časopis za suvremenu povijest 17/1: 141-157.

GOLDSTEIN, Ivo. 2008. Hrvatska 1918-2008. Zagreb: Novi liber, Europapress holding.

GOLDSTEIN, Ivo, Slavko GOLDSTEIN. 2015. Tito. Zagreb: Profil.

JAKOVINA, Tvrtko (ur.). 2012. Hrvatsko proljeće 40 godina poslije. Zagreb: Centar za demokraciju i pravo Miko Tripalo, Filozofski fakultet, Fakultet političkih znanosti, Pravni fakultet.

KRAŠIĆ, Wollfy. 2016. Hrvatsko proljeće i hrvatska politička emigracija. Doktorska disertacija, Filozofski fakultet Sveučilišta u Zagrebu. 
KUŠAN, Jakša. 2000. Bitka za Novu Hrvatsku. Rijeka: Otokar Keršovani.

MATIŠIĆ, Mislav. 2017. Londonska Nova Hrvatska o političkim događajima u Hrvatskoj i Jugoslaviji 1980-ih godina. Diplomski rad, Filozofski fakultet Sveučilišta u Zagrebu. MIJATOVIĆ, Anđelko. 2009. Bruno Bušić - prilog istraživanju života i djelovanja (1939.1978.): u prigodi 30. obljetnice mučkoga ubojstva. Zagreb: Školska knjiga.

MUJADŽEVIĆ, Dino. 2011. Bakarić: politička biografija. Zagreb: Plejada.

PONOŠ, Tihomir. 2007. Na rubu revolucije: studenti '71. Zagreb: Profil International.

RADELIĆ, Zdenko. 2008. Hrvatska u Jugoslaviji 1945.-1991.: od zajedništva do razlaza. Zagreb: Hrvatski institut za povijest.

SADKOVICH, James J. 2010. Tuđman: prva politička biografija. Zagreb: Večernji posebni proizvodi.

ŠENTIJA, Josip. 2012. Što je zapravo bilo Hrvatsko proljeće? O 40-toj godišnjici sloma. U Hrvatsko proljeće 40 godina poslije, ur. Tvrtko Jakovina, 3-15. Zagreb: Centar za demokraciju i pravo Miko Tripalo, Filozofski fakultet, Fakultet političkih znanosti, Pravni fakultet.

TRIPALO, Miko. 1990. Hrvatsko proljeće. Zagreb: Globus.

\section{Franjo Mikulić's recollections of the "Croatian Spring"}

Croatian reform movement, also popularly known as the "Croatian spring", was a process which could be described as a period of political, cultural and social upheaval, supported by a part of the Croatian League of Communists in the late 1960s and the early 1970s with the aim of creating a space of greater autonomy in relation to the federal centre, putting forward ideas that were broadly and more radically accepted by the wider populace. In the latter, the roles played by Matica hrvatska, cultural institution with the longest tradition in Croatia, and the student movement were particularly noted. After the Croatian spring was broken down, a period called "hrvatska šutnja", or "Croatian silence", followed. Parts of Croatian society came under repression. It was not possible in the Yugoslav communist regime for political opposition to freely express opinion, so it was also not possible to overtly talk about experiences of the Croatian reform movement, nor to publish texts about the subject. However, a small group of political émigrés left Yugoslavia. They included Franjo Mikulić, a mid-level member of the Croatian League of Communists, who knew and cooperated with many of the main protagonists of Croatian reform movement. In the early 1980s, magazine Hrvatski tjednik from Australia, serialised Mikulić's recollections regarding his political agenda during the Croatian reform movement. It also contained his depiction of various persons, those who took some part in events in Croatia at that time. Josip Broz Tito was not an exception. Mikulić's descriptions are not mainly black and 
white; he approaches the topic in a more complex and refined way. Those texts represent an important historiographic source, particularly because they appeared almost a decade before first works on the subject in Croatia.

Keywords: Franjo Mikulić, Croatian reform movement, Croatian political emigrant community, Matica hrvatska, Hrvatski tjednik.

Ključne riječi: Franjo Mikulić, hrvatski reformni pokret, hrvatska politička emigracija, Matica hrvatska, Hrvatski tjednik.

Wollfy Krašić

Miroslava Vaupotića 2, HR-10000 Zagreb krasicw1@gmail.com 


\section{FILOZOFSKI FAKULTET SVEUČILIŠTA U ZAGREBU \\ ZAVOD ZA HRVATSKU POVIJEST \\ INSTITUTE OF CROATIAN HISTORY \\ INSTITUT FÜR KROATISCHE GESCHICHTE}

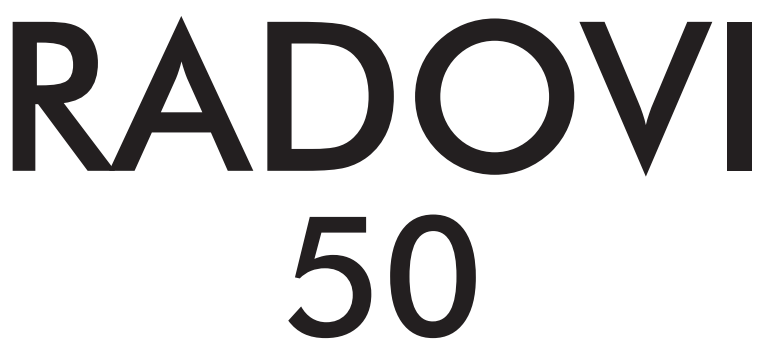

BROJ 2

ZAVOD ZA HRVATSKU POVIJEST

FILOZOFSKOGA FAKULTETA SVEUČILIŠTA U ZAGREBU

\section{FF press}

ZAGREB 2018. 


\title{
RADOVI ZAVODA ZA HRVATSKU POVIJEST FILOZOFSKOGA FAKULTETA SVEUČILIŠTA U ZAGREBU
}

\author{
Knjiga 50, broj 2
}

\author{
Izdavač / Publisher \\ Zavod za hrvatsku povijest \\ Filozofskoga fakulteta Sveučilišta u Zagrebu \\ FF-press \\ Za izdavača / For Publisher \\ Vesna Vlahović Štetić \\ Glavni urednik / Editor-in-Chief \\ Hrvoje Gračanin \\ Izvršni urednik / Executive Editor \\ Nikola Anušić \\ Uredništvo / Editorial Board
}

Bruna Kuntić-Makvić (stara povijest/ancient history), Zrinka Nikolić Jakus (srednji vijek/

medieval history), Hrvoje Petrić (rani novi vijek/early modern history), Željko Holjevac (moderna povijest/modern history), Tvrtko Jakovina (suvremena povijest/contemporary history),

Silvija Pisk (mikrohistorija i zavičajna povijest/microhistory and local history),

Zrinka Blažević (teorija i metodologija povijesti/theory and methodology of history)

Međunarodno uredničko vijeće / International Editorial Council

Denis Alimov (Sankt Peterburg), Živko Andrijašević (Nikšić), Csaba Békés (Budapest), Rajko Bratož (Ljubljana), Snježana Buzov (Columbus, Ohio), Svetlozar Eldarov (Sofija), Toni Filiposki

(Skopje), Aleksandar Fotić (Beograd), Vladan Gavrilović (Novi Sad), Alojz Ivanišević (Wien),

Egidio Ivetić (Padova), Husnija Kamberović (Sarajevo), Karl Kaser (Graz),

Irina Ognyanova (Sofija), Géza Pálffy (Budapest), Ioan-Aurel Pop (Cluj),

Nade Proeva (Skopje), Alexios Savvides (Kalamata), Vlada Stanković (Beograd),

Ludwig Steindorff (Kiel), Peter Štih (Ljubljana)

Izvršni urednik za tuzemnu i inozemnu razmjenu /

Executive Editor for Publications Exchange

Martin Previšić

Tajnik uredništva / Editorial Board Assistant

Dejan Zadro

Adresa uredništva/Editorial Board address

Zavod za hrvatsku povijest, Filozofski fakultet Zagreb, Ivana Lučića 3, HR-10 000, Zagreb

Tel. ++385 (0)1 6120 150, 6120 158, faks ++385 (0)1 6156879

Časopis izlazi jedanput godišnje / The Journal is published once a year

Časopis je u digitalnom obliku dostupan na / The Journal in digital form is accessible at

Portal znanstvenih časopisa Republike Hrvatske „Hrčak“ http://hrcak.srce.hr/radovi-zhp

Financijska potpora za tisak časopisa / The Journal is published with the support by Ministarstvo znanosti, obrazovanja i športa Republike Hrvatske

Časopis je indeksiran u sljedećim bazama / The Journal is indexed in the following databases: Directory of Open Access Journals, EBSCO, SCOPUS, ERIH PLUS, Emerging Sources Citation Index - Web of Science 


\title{
Naslovna stranica / Title page by
}

Iva Mandić

\section{Grafičko oblikovanje i računalni slog / Graphic design and layout Marko Maraković}

\author{
Lektura / Language editors \\ Samanta Paronić (hrvatski / Croatian) \\ Dražen Nemet (engleski / English)
}

Tisak / Printed by

Tiskara Zelina, Sv. Ivan Zelina

Naklada / Issued

200 primjeraka / 200 copies

Časopis je u digitalnom obliku dostupan na Portalu znanstvenih časopisa Republike Hrvatske „Hrčak“ http://hrcak.srce.hr/radovi-zhp

The Journal is accessible in digital form at the Hrcak - Portal of scientific journals of Croatia http://hrcak.srce.hr/radovi-zhp 